\title{
Distribution and lability of land-derived organic matter in the surface sediments of the Rhône prodelta and the adjacent shelf (Mediterranean Sea, France): a multi proxy study
}

\author{
S. Bourgeois ${ }^{1,2}$, A. M. Pruski ${ }^{1,2}$, M.-Y. Sun ${ }^{3}$, R. Buscail ${ }^{4}$, F. Lantoine ${ }^{1,2}$, P. Kerhervé ${ }^{4}$, G. Vétion ${ }^{1,2}$, B. Rivière ${ }^{1,2}$, and \\ F. Charles ${ }^{1,2}$ \\ ${ }^{1}$ UPMC Univ Paris 06, FRE 3350, LECOB, Observatoire Océanologique, 66650, Banyuls/Mer, France \\ ${ }^{2}$ CNRS, FRE 3350, LECOB, Observatoire Océanologique, 66650, Banyuls/Mer, France \\ ${ }^{3}$ Department of Marine Sciences, University of Georgia, Athens, GA 30602-3636, USA \\ ${ }^{4}$ Centre de Formation et de Recherche sur les Environnements Méditerranéens (CEFREM), UMR 5110-CNRS-Université de \\ Perpignan, 66860 Perpignan, France
}

Received: 10 February 2011 - Published in Biogeosciences Discuss.: 29 March 2011

Revised: 31 July 2011 - Accepted: 17 October 2011 - Published: 2 November 2011

\begin{abstract}
The Gulf of Lions is a river-dominated ocean margin that receives high loads of nutrients and particulate matter from the Rhône River but most particulate materials settle rapidly on the nearshore seafloor. One question is raised on the fate of these large quantities of organic carbon delivered by the river to the coastal marine environment. Surface sediments $(0-0.5 \mathrm{~cm})$ were collected in the Rhône prodelta and its adjacent shelf during a period of low river discharge (April 2007, 16 stations). The sources, distribution and lability of sedimentary organic matter were examined using bulk (organic carbon, total nitrogen, stable carbon isotope ratios, and grain size) and molecular-level (pigments, amino acids, fatty acids, and $\delta^{13} \mathrm{C}$ of individual fatty acids) analyses. Our results confirmed previous observations of a southwestward Rhodanian imprint in the nearshore sediments, with $97 \%$ of terrigenous inputs of organic matter near the river mouth. Isotopic values of bulk organic carbon, as well as fatty acid biomarkers and compound-specific $\delta^{13} \mathrm{C}$ signatures of most fatty acids clearly indicate that the Rhône inputs consist of a mixture of organic matter $(\mathrm{OM})$ from different origins with a strong contribution from terrestrial sources (soil and plant debris), and a smaller input from freshwater microalgae, mostly diatoms. The influence of the Rhône River was prominent within the first ten kilometers, but may still be observed on the outer shelf $(\sim 21 \mathrm{~km})$ as indicated by the occurrence of long chain fatty acids, which are derived from vascular plants, and their $\delta^{13} \mathrm{C}$ signatures. In the proximal prodelta,
\end{abstract}

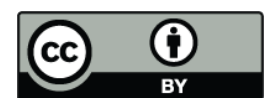

Correspondence to: A. M. Pruski (audrey.pruski@obs-banyuls.fr) bacteria-specific fatty acids were abundant $\left(1.65 \mathrm{mg} \mathrm{g}^{-1} \mathrm{OC}\right.$ at the mouth site) and were relatively depleted in $\delta^{13} \mathrm{C}$ confirming that bacteria mostly utilize land-derived OM. In the shelf area, the inputs of marine OM and its predominant utilization by the bacteria was confirmed, but the coupling between the pelagic and the benthic compartments appeared limited at this period of the year.

Overall, degradation indexes based on amino acids (Dauwe's degradation index) and pigments (ratio of intact chlorophyll- $a$ to the sum of chlorophyll- $a+$ phaeopigment$a$ ), as well as isotopic enrichment of source-specific fatty acids reveal an offshore gradient of OM decay reflecting the rapid deposition of the terrestrial material in the prodelta, the low mixing with $\mathrm{OM}$ deriving from marine sources and the efficient degradation of the OM. The OM delivered by the Rhône is relatively labile based on the intermediary value of Dauwe's degradation index, the high proportion of bioavailable nitrogen and the occurrence of polyunsaturated fatty acids. Deltaic sediments off the Rhône River should thus be of sufficiently high nutritional quality to sustain dense macrofaunal communities.

\section{Introduction}

River-dominated ocean margins (McKee et al., 2004) have received broad attention over the last decades from oceanographers because of their importance in transporting high loads of sediment and particulate organic matter from rivers to marine environments. Benthic boundary layer and seabed of coastal regions impacted by major rivers are very active

Published by Copernicus Publications on behalf of the European Geosciences Union. 
zones of biogeochemical transformations (Aller, 1998) and form the most remarkable repository of sediments and organic matter (OM) on Earth (Hedges and Keil, 1995). Within this general framework, one of the goals of the French program CHACCRA (Climate and Human-induced Alterations in Carbon Cycling at the River-seA connection) was to characterize the processes that govern the cycling and fate of organic particles in the superficial sediment of the Mediterranean coastal margin dominated by the Rhône River.

The Rhône River (France) transports annually 1.2 to $19.4 \times 10^{6} \mathrm{~T}$ of suspended matter to the adjacent continental shelf of the Gulf of Lions in the north-western Mediterranean Sea (Pont et al., 2002) and has been estimated to ac-

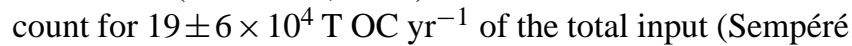
et al., 2000). Most of this matter accumulates rapidly in the delta front area where deposition dynamics are reinforced by flocculation processes (Aloisi et al., 1982). This results in maximum sediment accumulation rates ranging from several tens of centimetres per year $\left(30-50 \mathrm{~cm} \mathrm{yr}^{-1}\right)$ in the immediate vicinity of the river mouth to only a few millimetres offshore (Charmasson et al., 1998; Radakovitch et al., 1999) raising the question of the fate of this organic carbon (OC) and bio-relevant materials delivered to the benthic boundary layer and seabed. If quantity is a crucial parameter for the carbon budget, then organic matter quality (as defined by its composition) is relevant to estimating the efficiency of biogeochemical transformation kinetics and nutritional relevance of the organic matter available for benthic organisms (Mayer et al., 1995). Natural organic matter is made of simple monomers and/or biopolymers such as proteins, carbohydrates and lipids, which are rapidly mineralized. This labile pool of organic matter rarely exceeds $20 \%$ of the total organic matter (Hedges et al., 2000; Ingalls et al., 2004), and represents the fraction that may undergo early diagenesis in coastal marine sediments.

The large amounts of terrigenous compounds deposited in deltaic systems are generally considered as refractory to decomposition due to the presence of lignin structures (De Leeuw and Largeau, 1993; in Sanchez-Garcia et al., 2009; for review see: Wakeham and Canuel, 2006). However, recent findings have questioned this paradigm. Several studies demonstrated that river suspended particulate matter is less degraded than coastal sediments (Unger et al., 2005a, b; Gaye et al., 2009; Ingalls et al., 2003) and is highly sensitive to microbial remineralization (Mayer et al., 2008). The lability of the Rhône inputs has been previously discussed with regard to the linkage with benthic community structure and intensity of bacterial remineralization in the sediments (Hermand et al., 2008; Lansard et al., 2008; Goineau et al., 2011; Rosenberg et al., 2003). The distribution and lability of OM sources in the Rhône prodelta and its adjacent shelf were inferred in these earlier studies from bulk biochemical descriptors (lipids, proteins and carbohydrates) and global geochemical composition ( $\mathrm{C} / \mathrm{N}$ ratios and stable isotopes) (Alliot et al., 2003; Tesi et al., 2007, and references above). These proxies are difficult to interpret when sediments contain a mixture of different sources of OM at different stages of decomposition as is the case in coastal environments (Kim et al., 2006). Molecular-level proxies, such as amino and fatty acids, may shed light on sources, quality and degradation state of sedimentary $\mathrm{OM}$ when $\mathrm{C} / \mathrm{N}$ ratios and stable isotopes are equivocal. Fatty acids (FA) in particular can be valuable tools for identifying OM origin when multiple sources are involved (Canuel, 2001) because the pathways leading to double bond insertion vary between plants and organisms. Moreover, the carbon isotopic composition of individual FAs is another tool for identification of the sources (Canuel et al., 1997; Dai and Sun, 2007).

The nutritional quality of sedimentary OM, which may be defined as the capability to fulfill the nutritional needs of benthic organisms, can also be studied using molecular analyses. First, OM digestibility may be assessed using the bio-mimetic approach of Mayer et al. (1995) which permits quantification of the digestibility of the proteinaceous fraction (Grémare et al., 2003). Secondly, food must provide sufficient amounts of essential macro and micronutrients because heterotrophic organisms cannot synthesize de novo some of these components. Detailed knowledge of the biochemical composition of sedimentary OM, in particular the amino acid and fatty acid profiles, may indicate potential nutritional deficiencies (Phillips, 1984). It should also be taken into account that nutritional quality may evolve, since compositional changes also occur during early diagenesis (Niggemann and Schubert, 2006). The amino acid-based index of degradation proposed by Dauwe and Middelburg (1998) enable to quantify these changes and allow to scale the state of OM decomposition (Dauwe et al., 1999).

In our study, a range of molecular-level proxies were combined to assess the origin and quality of sedimentary OM in the surface deposits of the Rhône prodelta and adjacent shelf. This allows for an accurate picture of the distribution of terrestrial versus marine $\mathrm{OM}$ with a focus on the lability of these different sources of OM.

\section{Material and methods}

\subsection{Study area}

The Gulf of Lions, located on the northern part of the western Mediterranean Sea, is a wave-dominated continental shelf strongly impacted by the Rhône River (Raimbault and Durrieu de Madron, 2003). This major river enters the sea $812 \mathrm{~km}$ from its alpine source and drains a total catchment area of $97800 \mathrm{~km}^{2}$ (Pont et al., 2002). With a mean annual discharge of $1700 \mathrm{~m}^{3} \mathrm{~s}^{-1}$, the Rhône represents the major freshwater and organic carbon input to the Mediterranean Sea (Pont, 1997; Sempéré et al., 2000). The dispersal system of the Rhône River in the micro-tidal Mediterranean Sea is characteristic of relatively low-energy margins with 
prograding deltas (McKee et al., 2004). Material sedimented in the immediate vicinity of the river mouth forms a muddy sand bar; the fine-grain prodelta sediments cover an area of $50 \mathrm{~km}^{2}$ (Lansard et al., 2009) of the inner shelf as a result of sediment remobilisation and displacement by waves and currents (Marion et al., 2010). On the outer shelf, the finest particles are dispersed by the flood river plumes which are deviated by the prevailing wind regime and the Liguro-Provençal Current to the southwest and onshore (Arnau et al., 2004). In the Rhône system, autochthonous primary production is limited in the immediate vicinity of the river mouth and on the inner part of the shelf by turbidity and density gradients between fresh and marine waters (Naudin et al., 2001; Pujo-Pay et al., 2006).

\subsection{Sample collection}

Sediment cores were collected in the prodelta and the adjacent shelf during a period of low river discharge $\left(698 \mathrm{~m}^{3} \mathrm{~s}^{-1}\right)$. The highest peak of water discharge before sampling occurred at the beginning of March (3-9) when daily flow rates exceeded $2800 \mathrm{~m}^{3} \mathrm{~s}^{-1}$. Sixteen stations were sampled between 19 and 30 April 2007 at depths from 25 to $98 \mathrm{~m}$ (Table 1 and Fig. 1). The stations were divided into two subregions: the prodelta area (A, B, $\left.\mathrm{K}^{\prime}, \mathrm{L}\right)$ and the shelf area (C, D, E, F, G, H, I, J, N, O, M, R2). Stations A, B, N, C, D, $\mathrm{E}$ and $\mathrm{F}$ are distributed along a south west (SW) longitudinal transect corresponding to the preferential direction of the Rhône River plume (Millot, 1990). The stations J (marine reference site) and R2 were located outside the influence of the Rhône River (Fig. 1).

Sediment cores $(9.5 \mathrm{~cm}$ diameter, $60 \mathrm{~cm}$ height) were collected with a multicorer MUC 8/100 (Oktopus GmbH, Germany). Laboratory analyses were done on three cores from each station except for stable carbon isotopes which were measured on one core. The first layer of sediment $(0-0.5 \mathrm{~cm})$ of each core was homogenized and conditioned onboard. At all stations, an aliquot was immediately frozen at $-20^{\circ} \mathrm{C}$ for bulk (OC, total nitrogen, stable carbon isotopes, grain size) and pigment analyses. Stations distributed along the south west longitudinal transect and the marine reference site (i.e. station $\mathrm{J}$ ) were subjected to a more detailed description of the biochemical characteristics. To determine amino acids, fatty acids and compound-specific stable isotopes, a second subsample was rapidly desalted (Pusceddu et al., 2005) before storage at $-20^{\circ} \mathrm{C}$. Except for grain size and pigment, sediments were freeze-dried prior to analyses.

Suspended particulate matter was also collected in the Rhône River in March 2007. The sampling station was located at Arles (about $48 \mathrm{~km}$ from the mouth). The particulate matter was recovered from forty liters of water by centrifugation and then freeze-dried. This material was subjected to the same analyses as the surface sediments from the south west longitudinal transect.

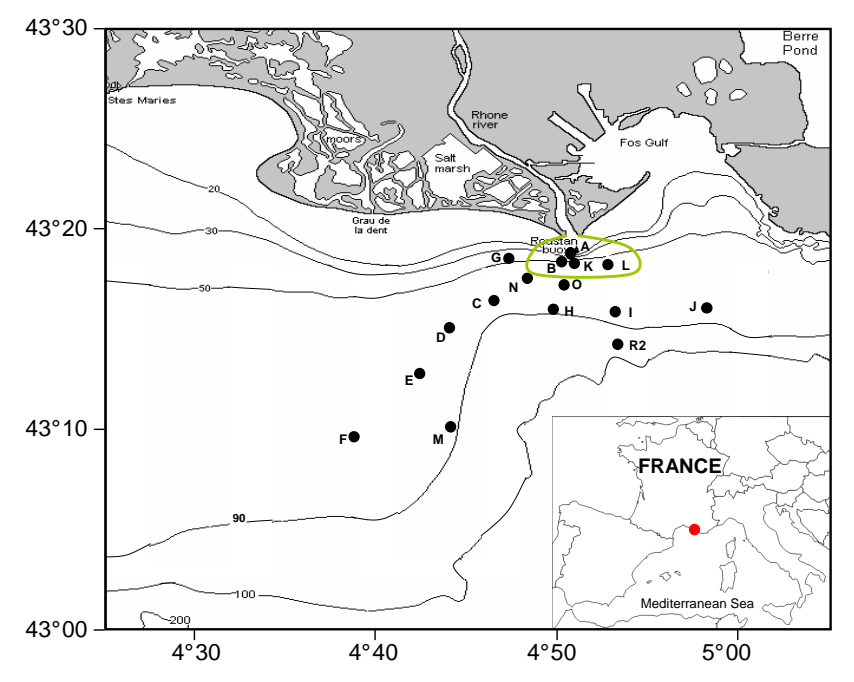

Fig. 1. Map of the Rhône River delta including the locations of sampling stations (April 2007). The green line defines the prodelta area of this study.

\subsection{Bulk analyses}

Sediment granulometry was measured using a Malvern ${ }^{\circledR}$ Mastersizer 2000 laser microgranulometer. Grain size is given as the $d(0.5)$, which corresponds to the median of the size distribution based on the equivalent spherical volume diameters.

Total nitrogen and organic carbon concentrations (TN and $\mathrm{OC}$, respectively) were analysed with an automatic $\mathrm{CN}$-analyzer LECO 2000 after acidification with $2 \mathrm{M} \mathrm{HCl}$ (overnight, at $50{ }^{\circ} \mathrm{C}$ ) to remove carbonates prior to the analyses of organic carbon (Cauwet et al., 1990). Precision for $\mathrm{OC}$ and TN measurements are $<2 \%$.

Stable carbon isotopes were measured on samples treated with $\mathrm{HCl}(2 \mathrm{M})$ to remove carbonate and then, subsequently rinsed with cold deionized water to remove chloride before freeze-drying (Schubert and Nielsen, 2000). An elemental analyzer (EA 3000 Eurovector) coupled with an Isotopic Ratio Mass Spectrometer (IR/MS, GVI Isoprime) was used. Isotopic results are given in the conventional $\delta$ notation:

$\delta^{13} C=\left[\left(\frac{R_{\text {sample }}}{R_{\text {standard }}}\right)-1\right] \cdot 1000$

where $R$ refers to ${ }^{13} \mathrm{C} /{ }^{12} \mathrm{C}$ ratio of the sample and the reference gas. Isotopic data are based on the international Vienna Pee Dee Belemnite (PDB) standard. The standard deviation for replicates of internal standards was better than $\pm 0.2 \%$ o for carbon isotopic ratios. Stable carbon isotope data has been reported in Cathalot et al. (2011). 

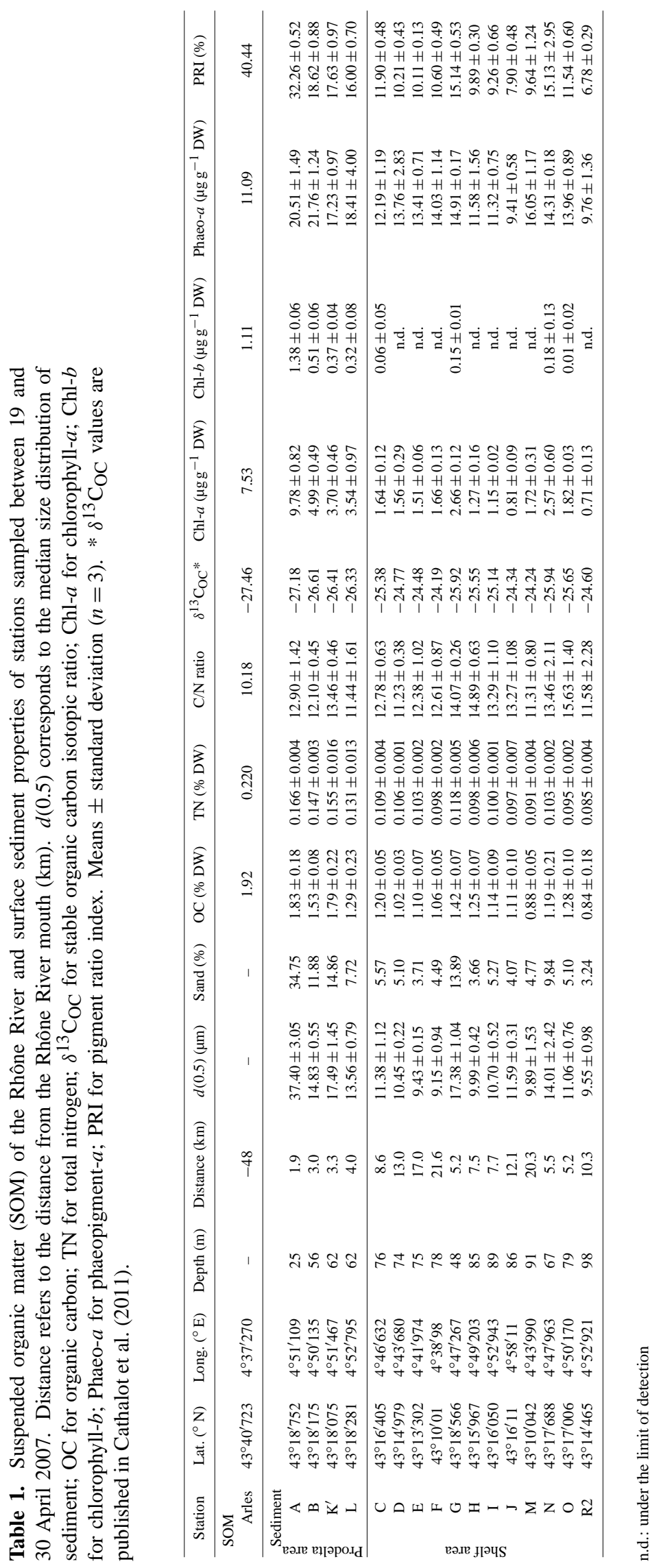


\subsection{Pigment analysis}

Extractions were performed in triplicate on each sediment sample. Sediments were rapidly thawed and $\sim 100 \mathrm{mg}$ were extracted overnight in $5 \mathrm{ml}$ of acetone at $5^{\circ} \mathrm{C}$ in the dark. Adjustment was made for sediment water content to obtain a final acetone concentration of $90 \%$. The fluorescence of the sediment extracts was measured on a LS 55 spectrofluorimeter (Perkin Elmer Inc., USA) according to the method developed by Neveux and Lantoine (1993) that allows the quantification of 4 pigments in sediments: chlorophylls- $a$, $-b$, and $-c$, and phaeopigments. The term "phaeopigments" refers to phaeophytin, phaeophorbide, and could also include some pyrophaeophytin, pyrophaeophorbide and even steryl chlorin esters since these compounds exhibit similar spectral bands that prevent their discrimination through spectral resolution. Concentrations were converted in $\mu \mathrm{g} \mathrm{g}^{-1}$ DW using water contents.

\subsection{Total hydrolysable and enzymatically hydrolysable amino acids}

Total hydrolysable amino acids (THAA) were extracted by acid hydrolysis and enzymatically hydrolysable amino acids (EHAA) following the biomimetic approach proposed by Mayer et al. (1995). THAA and EHAA hydrolysates were analysed as isoindole derivatives following reaction with an orthophtaldialdehyde solution and the fluorescent derivatives obtained were separated by reverse-phase high-performance liquid chromatography (HPLC, Gynkotek-Dionex system) using non-linear gradient of methanol-acetate buffer, and detected by fluorescence at $450 \mathrm{~nm}$ using an excitation wavelength of $335 \mathrm{~nm}$. The identification was based on retention times within a C18 HPLC column (Lindroth and Mopper, 1979) and the concentration of identified amino acids were calculated on the basis of individual calibration curves obtained for a mixture of 21 amino acids from the amino acid standard solution AA-S-18 (Sigma-Aldrich) to which 6 amino acids were added (asparagine, $\beta$-alanine, glutamine, taurine, ornithine, $\beta$-glutamic acid). The molar concentrations of 15 amino acids were converted as weight per gram of dried sediment ( $\mathrm{mg} \mathrm{g}^{-1} \mathrm{DW}$ ) for unit homogeneity with the other biochemical proxies. Tryptophan and cysteine are not quantified by this method; the former is destroyed during the hydrolysis step and the latter produces derivatives with minimal fluorescence. Moreover, aspartic acid and glutamic acid peaks include the contribution of the corresponding deaminated amino acids, glutamine and asparagine, a typical artefact of the method.

\subsection{Fatty acid analysis}

Fatty acid analyses were extracted by direct transesterification as previously described in Nahon et al. (2010). Approximately $1.5 \mathrm{~g}$ of dried sediments were allowed to react with a solution of methanol, sulfuric acid and chloroform
$(1.7: 0.3: 2, \mathrm{v} / \mathrm{v} / \mathrm{v})$ in the presence of an antioxidant (buthylhydroxytoluene, Christie, 2003). This procedure enables in one single step to extract the lipid and release the fatty acids that will be transformed in the corresponding methyl esters (FAMEs). An internal standard (nonadecanoic acid) was added to the extraction vials to account for potential loss or errors during the extraction procedure. The organic phase containing the FAMEs was recovered by three successive rinses and an aliquot of this phase was evaporated to dryness in a rotary evaporator (Savant Speed Vac system) at room temperature. FAMEs were redissolved in hexane prior to analysis by gas chromatography with mass spectrometry detection according to conditions described in Nahon et al. (2010). The instrument was a Varian 3900 coupled to a Saturn 2100T ion trap detector. Fatty acids as methyl esters were separated on a fuse silica capillary factor four VF- $23 \mathrm{~ms}$ column $(30 \mathrm{~m} \times 0.25 \mathrm{~mm}$ ID, $0.25 \mu \mathrm{m}$ thickness $)$ from Varian. FAMEs in samples were identified by comparison of retention times and mass spectra with authentic commercial standards: Qualmix Fish Synthetic (Ladoran Fine Chemicals, INTERCHIM, France), Supelco 37, PUFA no. 1 and no. 3 (SUPELCO, France). Qualitatively, the contribution of each individual fatty acid was determined on the basis of the reconstructed integrated chromatogram and expressed as the percentage of the specific compound area to the total peak area (\% of total fatty acids). Using a standard containing known amounts of FAMEs (Supelco 37), calibration curves were generated for 37 individual FAMEs by plotting the surface area of the quantifying ion as a function of FAME concentration. Fatty acid concentrations in the sediments were calculated using these calibration curves, corrected with the internal standard and expressed as weight per dry weight $\left(\mathrm{mg} \mathrm{g}^{-1} \mathrm{DW}\right)$.

\subsection{Compound specific stable isotope analysis}

Stable carbon isotopic compositions of individual fatty acids were determined using a GC-C-IRMS system (Agilent 6890 gas chromatograph/on-line combustion/Thermo DELTA plus $\mathrm{V}$ isotope ratio mass spectrometer). FAMEs were separated with a $30 \mathrm{~m} \times 0.25 \mathrm{~mm}$ i.d. column (DB-5, J\&W Scientific) and then combusted to $\mathrm{CO}_{2}$ over $\mathrm{CuO} / \mathrm{Pt}$ wires at $850^{\circ} \mathrm{C}$. The $\delta^{13} \mathrm{C}$ values of individual compounds were calculated based on working reference gas (UHP $\mathrm{CO}_{2}$ for $\delta^{13} \mathrm{C}$ ), which was calibrated to international reference materials PDB for $\delta^{13} \mathrm{C}$ using NIST (National Institute for Standards and Technology) reference materials (measured on Finnigan MAT 252 IRMS) and University of Indiana $n$-alkane reference mixtures (measured on Thermo Delta plus V GC/IRMS). The relative standard deviation of IRMS was less than $\pm 0.5 \%$ o for two internal standard measurements $(n=38)$. The $\delta^{13} \mathrm{C}$ values of fatty acids were calculated by correcting for the extra carbon atom (its isotopic composition being measured on Finnigan MAT 252 IRMS) in the FAMEs added during extraction/methylation. 


\subsection{Data treatment}

A two end-member model of ${ }^{13} \mathrm{C}_{\mathrm{OC}}$ signatures has been used to estimate the fraction of terrigenous organic carbon (Gordon and Goñi, 2003) with the following assumption: OC is composed exclusively of terrestrial OM delivered by the Rhône River $\left({ }^{13} \mathrm{C}_{\mathrm{OC}}\right.$ of Rhodanian suspended organic matter $(\mathrm{SOM})=-27.4 \%$, mean of a monthly survey from 2006 to 2008, Kerhervé unpublished results) and marine OM $\left({ }^{13} \mathrm{C}_{\mathrm{OC}}=-20.1 \%\right.$, Harmelin-Vivien et al., 2008).

The percentages of OC contained in THAA, EHAA and fatty acids were inferred from individual compound concentrations and number of carbon atoms in each compound. The percentages of $\mathrm{N}$ in the form of protein amino acids (THAA$\mathrm{N} \%$ ) and bioavailable amino acids (EHAA-N\%) were determined in the same way.

The amino acid degradation index (DI) proposed by Dauwe and Middelburg (1998) and revised in Dauwe et al. (1999) was calculated for our THAA data set. The calculation of the DI is based on the results of a PCA analysis performed on a suite of samples of varying degradation state from OM sources to sediments. The first axis of the PCA reflects OM degradation; the DI of a sample is defined as its value on the first axis of the PCA, which is the sum of the contributions of each amino acid (in molar \%), standardized within the reference data set and weighted by the respective factor coefficient.

$\mathrm{DI}=\sum_{i}\left[\frac{\operatorname{var}_{i}-\mathrm{AVGvar}_{i}}{\mathrm{STDvar}_{i}}\right] \cdot{\text { fac. } \operatorname{coef}_{i}}$

In the equation, $\operatorname{var}_{i}$ is the molar percentage of amino acid $i$ in a given data set, while AVG $\operatorname{var}_{i}$, STD $\operatorname{var}_{i}$ and fac.coef ${ }_{i}$ are given by Dauwe et al. (1999) and correspond to the mean, standard deviation and PCA-derived loading of amino acid $i$.

Positive DI values are indicative of fresh material such as phytoplankton $(+1.5)$ and negative values suggest that the OM has undergone degradation ( -2.2 for highly degraded; Dauwe and Middelburg, 1998). The DI is considered as a robust parameter because it is based on a large number of individual measurements (Meckler et al., 2004) and allows comparing directly and quantitatively samples from different sources and regions (Dittmar et al., 2001).

Caution should be applied when comparing our DI values with data from the literature since we did not include methionine in the calculation of the DI. This has little influence on DI values as they remain unchanged when methionine molar percentages equivalent to those reported in Dauwe et al. (1999) were used with our data. A methionine molar percentage fixed at $0 \%$ would subtract 0.16 from the values reported in the present paper.

All correlation analyses performed in this study use Pearson's correlation coefficients. $p$-values below 0.05 are considered statistically significant. A Principal Component Analysis (PCA) was performed to test the potential linkage between the origin and the lability of the sedimentary OM.
All the statistical procedures were done using either $\mathrm{R}$ or PAST software packages (Hammer et al., 2001).

\section{Results}

\subsection{Sediment bulk properties}

\subsubsection{Grain size}

Average grain size (Table 1) was positively correlated with distance from the river mouth ( $p<0.0001,16$ stations, $n=$ 48 ). Fine to very-fine muddy material (silt and clay, $<63 \mu \mathrm{m}$ ) was dominant in the surface sediments and accounted for between $65 \%$ and $97 \%$, with the highest percentages in the outermost sites. The proportion of sands $(>63 \mu \mathrm{m})$ was high in nearshore sediments $(\sim 35 \%$ at station $\mathrm{A})$ and decreased significantly with the distance to the river mouth $(p<0.001$, 16 stations, $n=48$ ) (Table 1$)$. Stations located close to Rhône River mouth (A, B, G and $\mathrm{K}^{\prime}$ ) were characterized by the presence of a coarser fraction $(>250 \mu \mathrm{m})$ that represented 2 to $6 \%$ of the matrix (data not shown).

\subsubsection{Elemental and isotopic composition of the organic matter}

Organic carbon and nitrogen contents, $\mathrm{C} / \mathrm{N}$ ratios and stable carbon isotope ratios are given in Table 1. Sediment organic carbon (OC) contents ranged from $0.84 \pm 0.18 \%$ to $1.83 \pm 0.18 \% \mathrm{DW}$ at stations $\mathrm{R} 2$ and A, respectively. Total nitrogen $(\mathrm{TN})$ contents ranged from $0.085 \pm 0.004 \%$ (station R2) to $0.166 \pm 0.004 \% \mathrm{DW}$ (station A). Stations distributed in the prodelta and adjacent shelf showed a general trend for decreasing $\mathrm{OC}$ and $\mathrm{TN}$ contents with the distance from the river mouth ( $p<0.0001$ in both cases, 16 stations, $n=48$ ). Rhodanian SOM was characterized by OC and NT contents of 1.92 and $0.220 \%$ DW.

$\mathrm{C} / \mathrm{N}$ atomic ratios ranged from $11.2 \pm 0.4$ to $15.6 \pm 1.4$. This ratio was also correlated with the distance from the river mouth ( $p<0.0001,16$ stations, $n=48)$, but not with depth ( $p=0.7252,16$ stations, $n=48)$. Values above 13 were characteristic of sediments located within the first ten $\mathrm{km}\left(\mathrm{A}, \mathrm{K}^{\prime}, \mathrm{G}, \mathrm{N}, \mathrm{O}, \mathrm{H}\right.$ and I). In the offshore area, C/N ratios were higher at stations $\mathrm{E}$ and $\mathrm{F}$, than at the deepest stations $\mathrm{M}$ and R2.

$\delta^{13} \mathrm{C}_{\mathrm{OC}}$ values of surface sediments ranged from $-27.18 \%$ nearby the inlet of the Rhône River to $-24.19 \%$ o $21.6 \mathrm{~km}$ offshore (Table 1 ). $\quad \delta^{13} \mathrm{C}_{\mathrm{OC}}$ value of Rhodanian SOM was $-27.46 \%$ o. $\delta^{13} \mathrm{C}_{\mathrm{OC}}$ values significantly decreased with distance from the river mouth ( $p<0.0002,16$ stations) and were correlated to the OC content $(p<0.0002,16$ stations). 


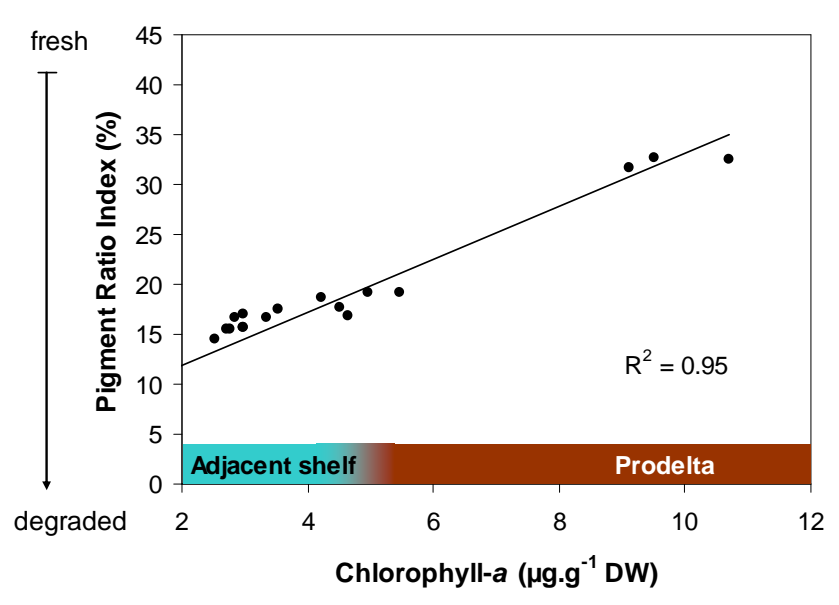

Fig. 2. Correlation between Pigment Ratio Index values (PRI \%) and chlorophyll- $a$ concentration in surface sediments off the Rhône River mouth (16 stations, 48 cores).

\subsection{Pigment concentration and composition}

Chlorophyll- $a$ in the study area showed a maximum near the shore $\left(9.78 \pm 0.82 \mu \mathrm{g} \mathrm{g}^{-1} \mathrm{DW}\right)$ and generally decreased seawards ( $p<0.0001,16$ stations, $n=48$, Table 1 ). Offshore, concentrations in the stations under the Rhône influence remained twice as high as at the marine reference site $(\mathrm{J})$, with values of $1.66 \pm 0.13$ and $0.81 \pm 0.09 \mu \mathrm{g} \mathrm{g}^{-1} \mathrm{DW}$ for stations $\mathrm{F}$ and $\mathrm{J}$, respectively.

Phaeopigments predominated over chlorophyll- $a$. The proportion of chlorophyll- $a$ to the sum of chlorophyll- $a$ and phaeopigments was used as a proxy of phytodetritus degradation (Pigment Ratio Index: PRI). This proxy was negatively correlated with distance from the mouth and water depth ( $p<0.0001$ in both cases, 16 stations, $n=48)$; values found in the Rhône River and at the mouth indicate that approximately 60 and $68 \%$ of the pigments were degraded, respectively (Table 1). Values decreased along the transect and more than $90 \%$ of chlorophyll- $a$ was degraded $9 \mathrm{~km}$ offshore. This trend was more pronounced on either side of the transect. Overall, the PRI was positively correlated with the chlorophyll- $a$ content $\left(R^{2}=0.95, p<0.0001,16\right.$ stations, $n=48$, Fig. 2).

Chlorophyll- $b$, an accessory pigment present in all Chlorophytes (Jeffrey, 1976), was only detected in sediments from stations located in the prodelta area and in the river SOM (Table 1).

\subsection{THAA and EHAA composition}

Total hydrolysable amino acid (THAA) concentrations in the sediments ranged from $2.23 \pm 0.06$ (station $\mathrm{F}$ ) to $3.77 \pm 0.30$ (station A) $\mathrm{mg} \mathrm{g}^{-1} \mathrm{DW}$ and decreased gradually to the southwest with distance from the mouth $(p<0.0001,7$ stations, $n=20$ ) (Table 2 ). When normalized per gram of organic car- bon, THAA values $\left(\mathrm{mg} \mathrm{g}^{-1} \mathrm{OC}\right)$ were no longer correlated with the distance from the mouth ( $p>0.05$, data not shown). Sediments from the furthermost stations contained approximately 1.7 times less THAA than at the mouth, and comparable amounts to the marine reference site $(\mathrm{J})$. The percentage of carbon contained in THAA made up 8.6 to $10.7 \%$ of the total organic carbon. THAA accounted for a large fraction of the $\mathrm{N}$ pool with minimal and maximal values recorded at stations B (32.2\%) and N (41.4\%), respectively (Table 2).

The acidic amino acids were predominant over the studied area. Aspartic acid (16.8-22.3 mole\%) prevailed over glutamic acid (11.1-12.0 mole\%). Two hydrophobic amino acids, glycine and alanine, were also abundant and accounted on average for 15.5 and 10.5 mole $\%$ of the amino acids respectively. Their contributions to the THAA pool were very consistent among stations with coefficients of variation lower than $4 \%$. Serine, threonine, valine and leucine accounted for between 5 and 10 mole\% of the THAA pool, whereas taurine, tyrosine, phenylalanine, isoleucine and the basic amino acids (histidine, arginine, lysine) never exceeded 4 mole $\%$ of the amino acids (Table 2).

Degradation index values tended to decrease from the mouth to stations located offshore (Fig. 3) with values of $0.096 \pm 0.163$ and $-0.434 \pm 0.235$ at stations A and F, respectively ( $p=0.0004,7$ stations, $n=20$; Table 2 ). DI values were positively correlated with $\mathrm{OC}, \mathrm{TN}$, pigments and PRI ( $p<0.05$ in all cases, 7 stations, $n=20)$.

Enzymatically hydrolysable amino acids (EHAA) in the surface sediments ranged from $0.53 \pm 0.06 \mathrm{mg} \mathrm{g}^{-1} \mathrm{DW}$ at the marine reference to $1.17 \pm 0.19 \mathrm{mg} \mathrm{g}^{-1} \mathrm{DW}$ at the mouth (Table 2). They decreased rapidly along the SW transect in the prodelta area, and then remained fairly constant offshore. They made up from $2.5 \%$ (station $\mathrm{N}$ ) to $3.0 \%$ (station $\mathrm{D}$ ) of the OC pool, and $8.5 \%$ (station B) to $9.8 \%$ (station D) of the $\mathrm{N}$ pool. Globally, the bioavailable amino acids had a composition similar to THAA.

The EHAA/THAA ratio was fairly constant in the surface sediments ( $27.5 \pm 1.76$ to $28.9 \pm 1.99 \%)$ except at station $\mathrm{N}$, where the ratio fell to $24.5 \pm 2.67 \%$ (Table 2). The ratio did not reveal any significant trend with distance from the coast or with water depth $(p>0.05$ in both cases, 7 stations, $n=20$ ).

\subsection{Distribution of fatty acid biomarkers}

Total fatty acid (FA) concentrations in the sediments

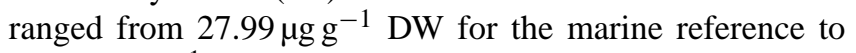
$160.03 \mu \mathrm{g} \mathrm{g}^{-1}$ DW at the river mouth (i.e. station A) (Table 3). A clear decrease of FA concentrations with increasing distance from the river mouth was observed along the southwest transect $\left(y=188.41 \cdot x^{-0.55}, R^{2}=0.90, p<0.0004,7\right.$ stations, $n=18$ ). In contrast to THAA, when normalized per gram of organic carbon, the southwestward decrease of FA was still evident with values falling from 8.74 to $3.75 \mathrm{mg} \mathrm{g}^{-1}$ OC $\left(y=9.75 \cdot x^{-0.33}, R^{2}=0.84, p<0.0001,7\right.$ stations, 
Table 2. Total (THAA) and enzymatically amino acid (EHAA) concentrations, contribution of THAA and EHAA to total organic carbon (THAA-C\% and EHAA-C\%) and total nitrogen (THAA-N\% and EHAA-N\%), EHAA/THAA ratio, amino acid composition as mole\% and Degradation Index (DI) in the suspended matter from the Rhône River (Arles station), surface sediments along the southwestern longitudinal transect $(\mathrm{A}, \mathrm{B}, \mathrm{N}, \mathrm{C}, \mathrm{D}, \mathrm{E}$ and F) and the marine reference site $(\mathrm{J})$. Means \pm standard deviation $(n=3)$. ASP $=\operatorname{aspartic}$ acid, GLU = glutamic acid, SER = serine, HIS = histidine, GLY = glycine, THR = threonine, ARG = arginine, TAU = taurine, ALA = alanine, $\mathrm{TYR}=$ tyrosine, $\mathrm{VAL}=$ valine, $\mathrm{PHE}=$ phenylalanine, $\mathrm{ILEU}=$ isoleucine, $\mathrm{LEU}=$ leucine, $\mathrm{LYS}=$ lysine.

\begin{tabular}{|c|c|c|c|c|c|c|c|c|c|c|}
\hline & Station & Arles & A & B & $\mathrm{N}$ & $\mathrm{C}$ & $\mathrm{D}$ & $\mathrm{E}$ & $\mathrm{F}$ & $\mathrm{J}$ \\
\hline \multirow{3}{*}{\multicolumn{2}{|c|}{$\begin{array}{c}\text { THAA }\left(\mathrm{mg} \mathrm{g}^{-1} \mathrm{DW}\right) \\
\text { THAA-C } \% \\
\text { THAA-N\% }\end{array}$}} & 4.57 & $3.77 \pm 0.30$ & $3.14 \pm 0.03$ & $2.82 \pm 0.35$ & $2.38 \pm 0.07$ & $2.54 \pm 0.09$ & $2.34 \pm 0.01$ & $2.23 \pm 0.06$ & $2.25 \pm 0.07$ \\
\hline & & 10.20 & $8.94 \pm 0.49$ & $9.66 \pm 1.82$ & $10.15 \pm 0.51$ & $8.49 \pm 0.05$ & $10.70 \pm 0.24$ & $8.92 \pm 0.62$ & $8.82 \pm 0.49$ & $8.60 \pm 0.74$ \\
\hline & & 31.87 & $34.46 \pm 3.63$ & $32.17 \pm 1.07$ & $41.36 \pm 4.37$ & $32.92 \pm 1.22$ & $36.40 \pm 1.64$ & $34.81 \pm 0.81$ & $34.95 \pm 1.83$ & $35.32 \pm 1.45$ \\
\hline \multicolumn{2}{|r|}{ EHAA $\left(\mathrm{mg} \mathrm{g}^{-1} \mathrm{DW}\right)$} & 1.29 & $1.17 \pm 0.19$ & $0.86 \pm 0.05$ & $0.68 \pm 0.02$ & $0.69 \pm 0.03$ & $0.72 \pm 0.04$ & $0.65 \pm 0.06$ & $0.64 \pm 0.03$ & $0.53 \pm 0.06$ \\
\hline \multicolumn{2}{|r|}{ EHAA-C $\%$} & 2.94 & $2.56 \pm 0.24$ & $2.71 \pm 0.51$ & $2.53 \pm 0.37$ & $2.50 \pm 0.21$ & $3.04 \pm 0.12$ & $2.54 \pm 0.12$ & $2.60 \pm 0.11$ & $2.09 \pm 0.37$ \\
\hline \multicolumn{2}{|r|}{ EHAA-N\% } & 8.54 & $9.38 \pm 0.59$ & $8.50 \pm 0.32$ & $9.54 \pm 0.12$ & $9.10 \pm 0.43$ & $9.76 \pm 0.42$ & $9.07 \pm 0.98$ & $9.46 \pm 0.67$ & $8.00 \pm 0.84$ \\
\hline \multicolumn{2}{|r|}{ EHAA/THAA } & 28.27 & $28.21 \pm 1.07$ & $27.49 \pm 1.76$ & $24.52 \pm 2.67$ & $28.91 \pm 1.99$ & $28.17 \pm 1.85$ & $27.71 \pm 2.78$ & $28.65 \pm 0.87$ & $23.74 \pm 2.33$ \\
\hline \multirow{16}{*}{ 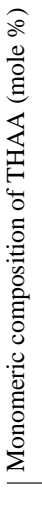 } & ASP & 14.44 & $16.83 \pm 0.04$ & $18.25 \pm 0.10$ & $19.34 \pm 0.39$ & $20.96 \pm 0.65$ & $21.56 \pm 0.17$ & $21.64 \pm 0.07$ & $22.31 \pm 0.70$ & $21.12 \pm 0.40$ \\
\hline & GLU & 10.02 & $12.03 \pm 0.56$ & $11.76 \pm 0.47$ & $11.34 \pm 0.19$ & $11.47 \pm 0.23$ & $11.57 \pm 0.10$ & $11.66 \pm 0.14$ & $11.38 \pm 0.26$ & $11.06 \pm 0.17$ \\
\hline & SER & 8.57 & $8.55 \pm 0.03$ & $8.83 \pm 0.16$ & $8.77 \pm 0.09$ & $8.96 \pm 0.17$ & $8.65 \pm 0.27$ & $8.52 \pm 0.08$ & $8.59 \pm 0.33$ & $7.95 \pm 0.25$ \\
\hline & HIS & 1.23 & $1.23 \pm 0.79$ & $1.23 \pm 0.65$ & $1.80 \pm 0.39$ & $0.64 \pm 0.74$ & $0.99 \pm 0.08$ & $2.09 \pm 0.40$ & $1.47 \pm 1.23$ & $1.26 \pm 0.46$ \\
\hline & GLY & 16.30 & $15.03 \pm 0.51$ & $15.59 \pm 0.54$ & $15.68 \pm 0.38$ & $15.91 \pm 0.12$ & $15.25 \pm 0.26$ & $15.58 \pm 0.16$ & $15.35 \pm 0.37$ & $15.53 \pm 0.22$ \\
\hline & THR & 7.93 & $7.06 \pm 0.06$ & $6.96 \pm 0.05$ & $6.91 \pm 0.05$ & $6.55 \pm 0.32$ & $7.13 \pm 0.07$ & $7.36 \pm 0.30$ & $7.15 \pm 0.37$ & $7.30 \pm 0.05$ \\
\hline & ARG & 3.75 & $2.80 \pm 0.03$ & $2.54 \pm 0.14$ & $2.47 \pm 0.16$ & $2.54 \pm 0.17$ & $2.61 \pm 0.09$ & $2.75 \pm 0.09$ & $3.00 \pm 0.26$ & $3.05 \pm 0.10$ \\
\hline & TAU & 0.10 & $0.09 \pm 0.00$ & $0.14 \pm 0.07$ & $0.16 \pm 0.03$ & $0.19 \pm 0.02$ & $0.20 \pm 0.08$ & $0.23 \pm 0.06$ & $0.20 \pm 0.08$ & $0.22 \pm 0.01$ \\
\hline & ALA & 12.83 & $10.97 \pm 0.10$ & $10.95 \pm 0.19$ & $10.80 \pm 0.15$ & $10.41 \pm 0.15$ & $10.58 \pm 0.17$ & $10.43 \pm 0.21$ & $10.06 \pm 0.13$ & $9.77 \pm 0.12$ \\
\hline & TYR & 2.06 & $1.70 \pm 0.13$ & $1.06 \pm 0.09$ & $2.49 \pm 0.52$ & $2.30 \pm 0.45$ & $2.62 \pm 0.09$ & $1.31 \pm 0.22$ & $1.58 \pm 0.16$ & $1.45 \pm 0.35$ \\
\hline & VAL & 5.04 & $6.08 \pm 0.08$ & $5.96 \pm 0.11$ & $5.22 \pm 0.20$ & $5.33 \pm 0.14$ & $5.13 \pm 0.16$ & $4.70 \pm 0.19$ & $4.98 \pm 0.08$ & $6.02 \pm 0.03$ \\
\hline & PHE & 3.47 & $3.57 \pm 0.07$ & $3.54 \pm 0.04$ & $3.21 \pm 0.12$ & $3.06 \pm 0.01$ & $3.11 \pm 0.10$ & $2.96 \pm 0.09$ & $2.83 \pm 0.07$ & $3.09 \pm 0.06$ \\
\hline & ILEU & 2.57 & $3.42 \pm 0.06$ & $3.13 \pm 0.06$ & $2.68 \pm 0.14$ & $2.80 \pm 0.09$ & $2.55 \pm 0.08$ & $2.37 \pm 0.05$ & $2.63 \pm 0.11$ & $3.18 \pm 0.06$ \\
\hline & LEU & 6.57 & $6.89 \pm 0.07$ & $6.25 \pm 0.16$ & $5.61 \pm 0.29$ & $5.49 \pm 0.10$ & $5.34 \pm 0.09$ & $5.23 \pm 0.15$ & $5.24 \pm 0.08$ & $5.21 \pm 0.06$ \\
\hline & LYS & 5.12 & $3.74 \pm 0.17$ & $3.81 \pm 0.06$ & $3.54 \pm 0.28$ & $3.38 \pm 0.04$ & $2.71 \pm 0.16$ & $3.17 \pm 0.13$ & $3.23 \pm 0.04$ & $3.80 \pm 0.01$ \\
\hline & DI & -0.27 & $0.10 \pm 0.16$ & $-0.17 \pm 0.14$ & $-0.04 \pm 0.07$ & $-0.33 \pm 0.18$ & $-0.33 \pm 0.04$ & $-0.38 \pm 0.06$ & $-0.44 \pm 0.24$ & $-0.39 \pm 0.14$ \\
\hline
\end{tabular}

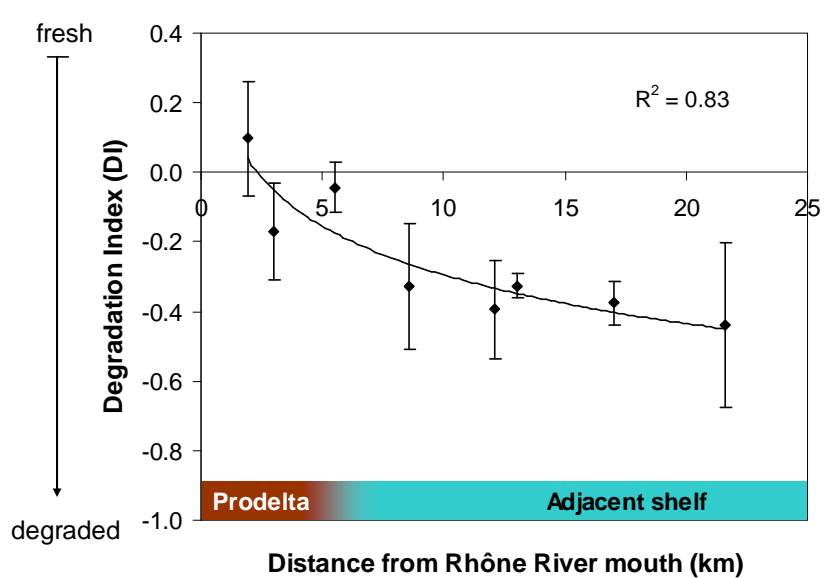

Fig. 3. Correlation between Degradation Index values (DI) and distance from the river mouth in the surface sediments ( 8 stations, 24 cores).

$n=18$ ) (Fig. 4). FA accounted for a small fraction of the organic carbon ranging from 0.17 to $0.63 \%$ for stations A and $\mathrm{J}$, respectively (data not shown).

Twenty eight individual fatty acids were identified, representing a wide range of $\mathrm{OM}$ inputs into the prodelta and

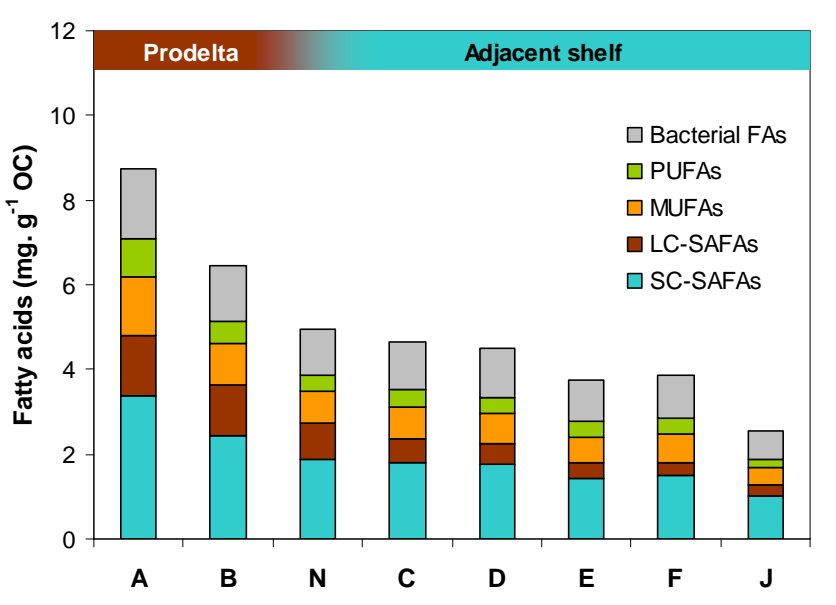

Fig. 4. Contribution of bacterial, polyunsaturated, monounsaturated, long chain saturated and short chain saturated fatty acids to the sedimentary organic matter $\left(\mathrm{mg} \mathrm{g}^{-1} \mathrm{OC}\right.$ ). Fatty acids were grouped as follows: Bacterial FAs = odd numbered saturated FAs; iso and anteiso FAs and vaccenic acid; PUFAs $=\mathrm{C}_{16}$ to $\mathrm{C}_{22}$ polyunsaturated FAs; MUFAs $=16: 1 \omega 7,18: 1 \omega 9$, 20:1 199 ; SCSAFAs $\leq \mathrm{C}_{20}$ even numbered saturated FAs; LC-SAFAs $>\mathrm{C}_{20}$ even numbered saturated FAs. 
Table 3. Individual fatty acid composition (\% area) and total FA concentrations in the suspended matter from the Rhône River (Arles station), surface sediments along the southwestern longitudinal transect (A, B, N, C, D, E and F) and at the marine reference site (J). Means \pm standard deviation $(n=3)$. nd: not detected.

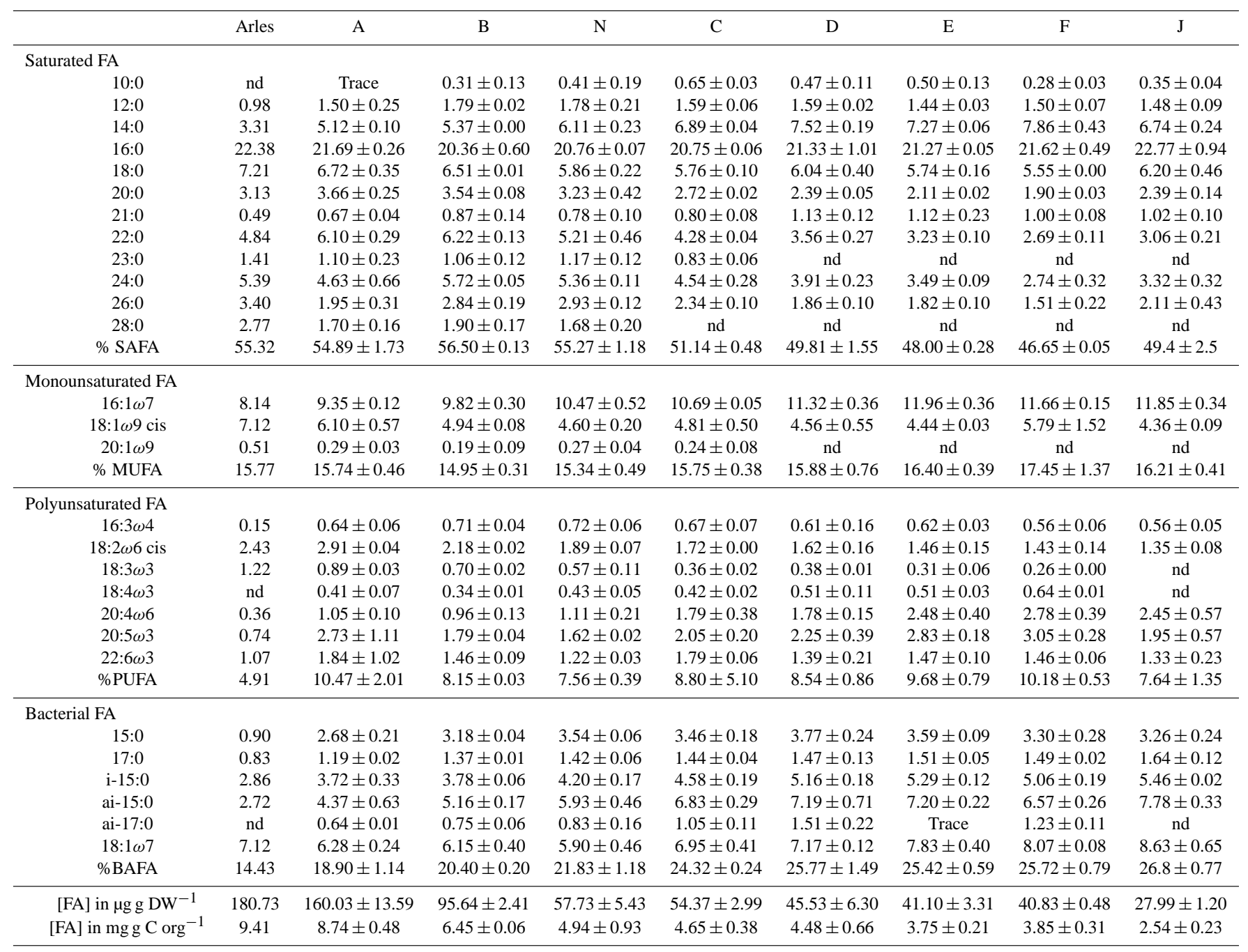

adjacent shelf. Identified fatty acids included short chain saturated fatty acids $\left(\mathrm{C}_{10}-\mathrm{C}_{20}\right)$, long chain saturated fatty acids $\left(\mathrm{C}_{22}-\mathrm{C}_{28}\right)$, monounsaturated fatty acids (MUFAs; e.g. 16:1 $\omega 7,18: 1 \omega 9$ cis and 20:1 $\omega 9$ ), polyunsaturated fatty acids

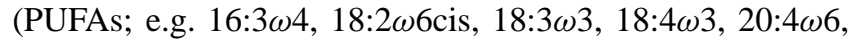
20:5 $\omega 3$ and 22:6 $\omega 3$ ), bacterial fatty acids (BAFAs; e.g. 15:0,

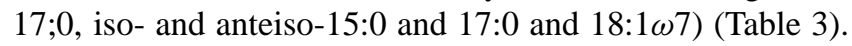
Source assignment was made according to the literature (see Sect. 4.1 below).

Overall, saturated fatty acids (SAFAs) were the most abundant series (46.65 to $56.50 \%$ ) of FAs, with the dominance of short chain SAFAs over long chain compounds $\left(\mathrm{C}_{22}-\mathrm{C}_{24}\right)$. The most abundant short chain SAFAs were 16:0 (>20\%) and to a lesser extent 18:0 (5.5-6.7\%) (Table 3). Long chain SAFAs were also abundant in stations located near the river mouth, but rapidly decreased with distance from the mouth ( $p<0.0001,7$ stations, $n=18$ ). Nonetheless, these biomarkers of terrestrial inputs were found in the surface sediments at all stations even at the marine reference site. The ratio of long chain even numbered fatty acids to short chain even numbered fatty acids (LCFA:SCFA) was comprised in the $0.2-0.5$ range. Bacterial FAs were found in all samples with relative contributions ranging from 18.9 to $26.8 \%$ of the FAs. Monounsaturated fatty acids (MUFAs) ranged from 15.3 to $17.4 \%$ of the FAs with $16: 1 \omega 7$ accounting for approximately one half of the MUFAs (Table 3). The proportion of polyunsaturated fatty acids (PUFAs) varied from 7.6 to $10.5 \%$ of the FAs and was marked by the dominance of 

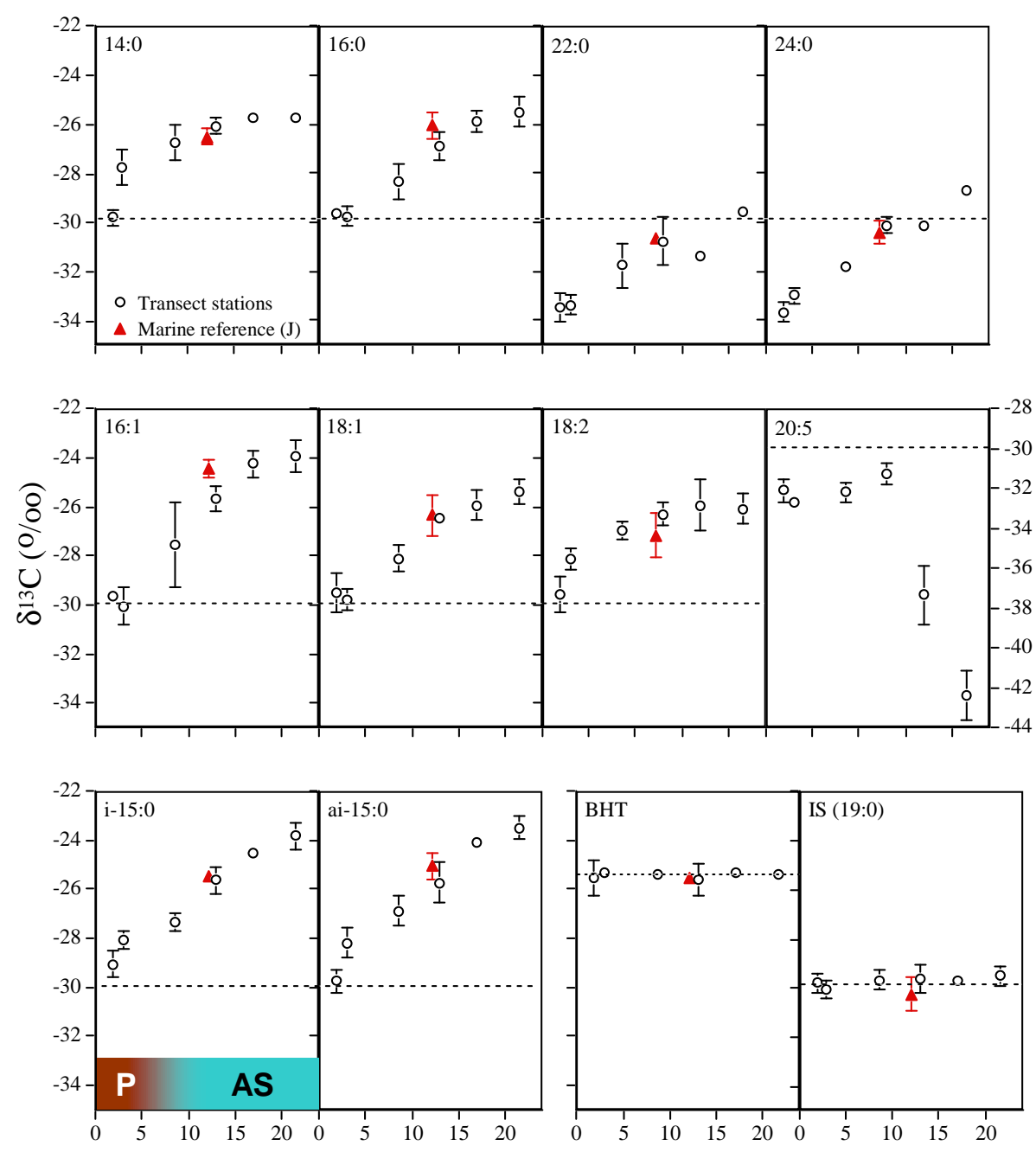

Distance from Rhône River mouth (km)

Fig. 5. Variations of $\delta^{13} \mathrm{C}$ of individual fatty acids in sediment samples collected along the prodelta-shelf transect (P and AS correspond to the prodelta and adjacent shelf, respectively). BHT stands for butylhydroxytoluene (antioxidant) and the Internal Standard (IS) used was nonadecanoic acid.

PUFAs belonging to the omega 3 series $(18: 3 \omega 3,18: 4 \omega 3$,

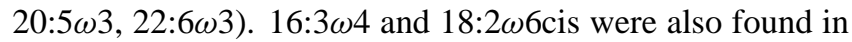
all samples.

\subsection{Variations of $\delta^{13} \mathrm{C}$ of individual fatty acids}

Compound-specific stable carbon isotopic compositions of 14 individual fatty acids were determined for sediment samples collected along the transect sites (A, B, C, D, E, and $\mathrm{F})$ and at one reference site $(\mathrm{J})$. Except two measurements of 20:5 at stations $\mathrm{E}$ and $\mathrm{F}$, the $\delta^{13} \mathrm{C}$ values of all fatty acids varied in a range from $-23 \%$ to $-34 \%$ (Fig. 5). For even-number saturated fatty acids, the $\delta^{13} \mathrm{C}$ values of $\mathrm{C}_{14-}$ $\mathrm{C}_{18}$ compounds were generally 3 to $4 \%$ o higher than those of $\mathrm{C}_{20}-\mathrm{C}_{26}$ compounds at each site. For other groups of fatty acids including monounsaturated (e.g. 16:1 and 18:1), branched (e.g. iso-15:0 and anteiso-15:0), odd-number saturated (e.g. 15:0), and one polyunsaturated (18:2) compound, their $\delta^{13} \mathrm{C}$ values varied in the same range as those $\mathrm{C}_{14}-\mathrm{C}_{18}$ saturated fatty acids. However, for $20: 5$ polyunsaturated fatty acid, the $\delta^{13} \mathrm{C}$ values varied differently from all other compounds and two unusual negative values were observed at stations $\mathrm{E}$ and $\mathrm{F}$.

Along the transect from the river mouth to offshore sites, the $\delta^{13} \mathrm{C}$ values of almost all fatty acids (except 20:5) shifted positively (Fig. 5). In general, approximately 4 to $6 \%$ enrichments were observed for all compounds but at station $\mathrm{D}$, the $\delta^{13} \mathrm{C}$ values of these fatty acids became to be equivalent to those found in the marine reference site (station J). The $\delta^{13} \mathrm{C}$ of the $20: 5$ fatty acid varied little from station A to D, but dropped at stations $\mathrm{E}$ and $\mathrm{F}$. 


\subsection{Multivariate analysis of OM quality, biomarkers of origin and physical characteristics}

The first axis of the PCA explains $63.58 \%$ of the total variation and is characterized by positive loadings for $\mathrm{C} / \mathrm{N}$ atomic ratio, Chl- $b$, PRI, OC, FA, DI and vascular plant FA markers. It is characterized by negative loadings for algal and bacterial FA markers and EHAA/THAA ratio (Fig. 6). The second axis of the PCA explained another $16.18 \%$ of the variation and has positive loadings for EHAA/THAA, algal and bacterial FA markers, FA, PRI, OC, Chl- $b$; and slightly negative loadings for $\mathrm{C} / \mathrm{N}$ ratio, DI and vascular plant FA markers.

\section{Discussion}

The main objective of the present study was to provide a picture of the distribution of terrestrial versus marine organic matter using molecular-level proxies, with a focus on the state of degradation and bioavailability of these different sources of OM. It is important to understand the fate of large quantities of organic carbon and bio-relevant materials delivered to the benthic boundary layer since most of the terrestrial particulate matter from the Rhône settles rapidly in the prodelta. Quantity obviously is a crucial parameter for carbon budget in river-dominated ocean margin (RiOMar) systems, but OM quality as defined by its composition at the molecular level is of critical relevance to appraise the efficiency of OM cycling and its nutritional potential for benthic organisms.

\subsection{Spatial distribution of continental and marine derived organic matter in surface deposits}

In spring 2007, low river discharge conditions possibly followed by high hydrodynamic sorting of settled particles resulted in the accumulation of coarser sediments with a high OC content nearshore, whereas OM associated with fine particles was transported seaward. Using a two end-member mixing model of $\delta^{13} \mathrm{C}_{\mathrm{OC}}$ values, we estimated that the terrigenous OC fraction accounted for up to $97 \%$ in the vicinity of the Rhône mouth whereas terrestrial and marine contributions were equivalent in the shelf area. The strong influence of the Rhône inputs on the sediment characteristics appears clearly in the PCA, with the marked opposition on the first axis of bulk characteristics (i.e. OC, median grain size) and the distance to the river mouth (Fig. 6a). This shows the importance of sediment dispersal patterns on the composition of the OM deposited on the continental shelf by the Rhône.

Molecular-level proxies presented here confirm the prevalence of continental OM in the sediments of the prodelta, and provide additional information on the different sources of $\mathrm{OM}$ that is not provided by stable isotopic analysis. Chlorophyll- $b$, an accessory pigment commonly ascribed to Chlorophytes, which include all vascular plants and also green algae (Jeffrey, 1976), was found only in the prodelta.
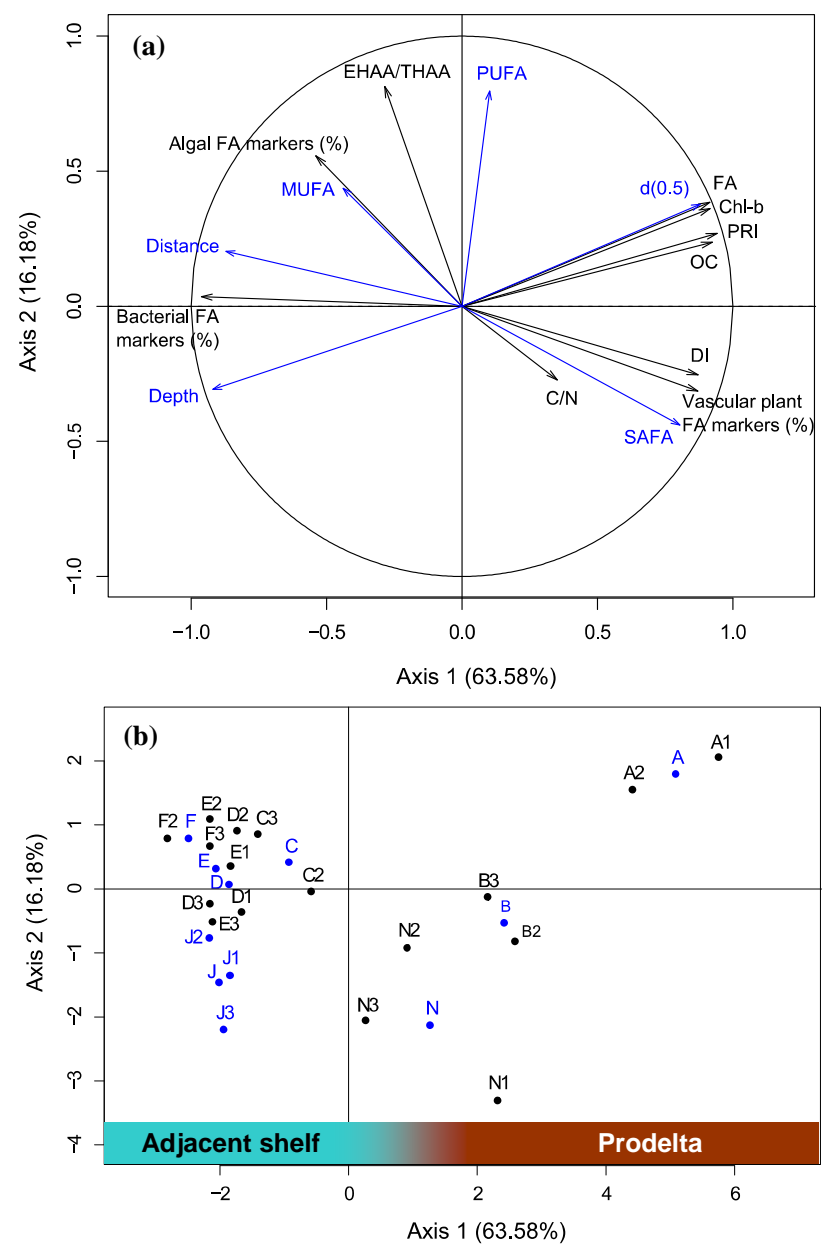

Fig. 6. Plot of loadings (a) and scores (b) for PCA of bulk and molecular-level characteristics of the OM from 7 stations located along a southwestward transect off the Rhône River and a marine reference site (station J). PCA was based on total fatty acid content (FA), vascular plant FA markers, bacterial FA markers, algal FA markers, pigment ratio index (PRI), organic carbon (OC), C/N ratio, chlorophyll- $b$ (Chl- $b$ ), degradation index (DI) and EHAA/THAA ratio (in black). Other scores (average for each station and the marine reference) and loadings (distance, depth, $d(0.5)$, \%SAFA, $\%$ MUFA, \%PUFA) were introduced as supplementary parameters (in blue).

Chlorophyll- $b$ content in the nearshore sediments closely matches the composition of suspended particles collected from the Rhône (Table 1). The contribution of chlorophyll- $b$ expressed as percentages of chlorophyll- $a$ was in the range of $10-14 \%$ at the river mouth and decreased seaward. Freshwater phytoplankton chlorophyll- $b$ has been previously observed throughout the year in POC from the Rhône River and accounted for less than $3 \%$ of the chlorophyll- $a$ even when phytoplankton blooms occurred (Harmelin-Vivien et al., 2010). The simultaneous presence of high concentrations of chlorophylls- $a$ and $-b$ in spring 2007 highlights the 
important contribution of terrestrial plant-derived $\mathrm{OM}$ to the muddy deposits in the vicinity of the Rhône mouth. Inputs of autochthonous OM may represent another substantial source of chloropigments in coastal margins (Mann, 1982; Day et al., 1989) as marine productivity in deltaic environments tends to be high because of significant nutrient inputs from riverine sources (Hedges and Keil, 1995; Lefevre et al., 1997). However, in the Rhône prodelta, the coupling between the pelagic and benthic compartments is likely reduced as suggested by the strong vertical salinity gradient between marine and river waters which limits exchanges between the nutrient-rich freshwater and potential consumers in the underlying marine water (Naudin et al., 2001). Besides, carbon fixation by microphytobenthos is certainly of minor importance in the Rhône prodelta as confirmed by the absence of oxygen oversaturation at the benthic boundary layer (see $\mathrm{O}_{2}$ profiles in Cathalot et al., 2010).

The contribution of various individual fatty acids characteristic of known organic matter sources were grouped and used as proxies of origin to evaluate the relative importance of autochthonous and allochthonous OM in the Rhône River delta system. Long chain even numbered FAs (LCFA) are derived from cuticular waxy leaf coatings of higher plants (Wannigama et al., 1981) and are fairly resistant to degradation (Philp, 1994). They are thus considered as good indicators of vascular plant inputs. Here, they were found in all samples (7.9-18.6\%) even in sediments from the marine reference station. Some marine microalgae might also produce small amounts of LCFA, which would then represent a marine source for these fatty acids (reviewed by Volkman et al., 1998). Nonetheless, the isotopic signature of these fatty acids was in the range of values previously reported for LCFA of terrestrial origin ( $-35 \%$ o to $-30 \%$, Shi et al., 2001). Since they are abundant in terrestrial plants, the oc-

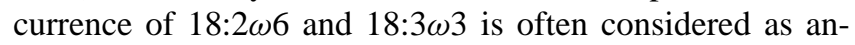
other indicator of terrestrial OM in coastal environments (Dai et al., 2005). However, these compounds are rapidly lost as plant tissues are decomposed (Wannigama et al., 1981), resulting in low concentrations in sediments. In our study, the contribution of these two fatty acids was small, but comparable to values reported in other coastal sediments with river inputs (1.2-3.2\%, Copeman and Parrish, 2003; $2.5 \%$, Budge et al., 2001; e.g. $3.9 \%$ at the level of the SW pass, Waterson, 2005). We found the concentrations of these two FAs decreased seaward and were the lowest at our marine reference site $(1.3 \%)$. This trend is consistent with the dispersal by the river plume (Naudin et al., 2001).

Based on the lignin content of the surface sediments, Tesi et al. (2007) have shown a relationship between the concentration of plant-derived detritus and the proportion of coarsegrained sediments, reflecting vertical and lateral sorting of particles in the Rhône River plume and benthic boundary layer. In our study, the terrestrial plant markers (chlorophyll$b$, LCFA, $18: 2 \omega 6+18: 3 \omega 3)$ were significantly correlated with the sand fraction ( $p<0.05$ in all cases). Plant-derived detritus behave like coarse particles and are retained within the innermost part of the prodelta, while the fine fraction is selectively transported seaward along the main sediment dispersal pathway. The occurrence of plant debris in the vicinity of the Rhône River mouth (station A) was also confirmed by visual observation of woody materials, vascular plant debris and even intact duckweeds in separate sediment grab samples.

The occurrence of PUFAs in marine sediments is generally considered as an indicator of fresh algal inputs. In the present study, it remains unclear whether the relatively moderate contribution of PUFAs reflects the reduced coupling between the water column and the benthic boundary layer at this period of the year or the enhanced degradation of these labile compounds by pre- and post-depositional processes. The contribution of PUFAs was highest at inshore and offshore stations (stations A and F, respectively), and had a minimum for the inner part of the adjacent shelf (station $\mathrm{N}$ located $5.5 \mathrm{~km}$ offshore; Fig. 6b). This also coincides with the distribution pattern of chlorophyll- $b$. The phytoplanktonic PUFAs found in the nearshore sediments could be derived from freshwater inputs, since it has been shown that the sharp salinity gradient does not allow marine phytoplankton species to develop in the vicinity of the Rhône River (Naudin et al., 2001). The distribution pattern of PUFA suggests two sources of planktonic fatty acids in the system: allochthonous freshwater algae delivered by the Rhône and autochthonous marine phytoplankton stimulated more offshore by riverine inputs of nutrients. Algal PUFAs were dominated by essential fatty acids of the omega 3 series: eicosapentaenoic acid (EPA; 20:5 $\omega 3$ ), a typical marker of marine but also freshwater diatoms, and to a lesser extent docosahexaenoic acid (DHA, 22:6 $\omega 3$ ), a FA mainly originating from dinoflagellates. EPA and DHA were found in suspended organic matter from the Rhône River (Table 3), consistent with the potential for inputs of freshwater microalgae.

The PUFA of the omega 6 series, arachidonic acid (ARA, 20:4 $\omega 6$ ), was found in the sediments with an increasing contribution at stations with a stronger marine influence (stations $\mathrm{F}$ and $\mathrm{J}$ ). The presence of this compound in the open sea is rather unusual as it is the most abundant FA of the freshwater flagellate protist Euglena gracilis. However, the trend, we observed, may be explained because a few marine microalgae are also able to produce this compound (Dunstan et al., 1994; Petkov et al., 1994; Nichols and Appleby, 1969; Hayashi et al., 1994). Together with the presence of some $\mathrm{C}_{16}$ and $\mathrm{C}_{18}$ PUFA, dominant in diatoms and flagellates, respectively, the abundance of $16: 1 \omega 7(9.3-12.0 \%)$, a FA common in diatoms, is additional evidence for the input of phytoplanktonic material to the sediments of the Rhône system. The succession of microalgal communities in the Rhône prodelta and adjacent shelf has not yet been described, but the changes in PUFA composition suggest a shift of planktonic communities in the stations under the direct influence of the Rhône River compared to those more impacted by 
marine inputs.

The contribution of zooplankton-derived organic material seems to be minor, since only trace amounts of $20: 1 \omega 9$, a FA that originates from fatty alcohols of copepod wax esters, were found in our samples (Sargent and Falk-Petersen, 1988; Sargent and Henderson, 1986).

Branched and odd straight-chain saturated FAs dominate in bacteria (Gillan and Hogg, 1984). Other markers include

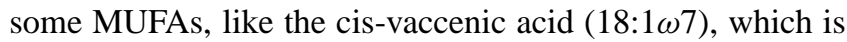
mainly of bacterial origin (Perry et al., 1979), but can also be produced by some microalgae (Nichols et al., 1984; Volkman et al., 1989). The contribution of all these bacterial FAs indicates a strong bacterial imprint in the surface sediments from the Rhône prodelta and adjacent shelf (18.9 and 26.8\% of total FAs at the inshore and marine reference stations, respectively). Nevertheless, we cannot determine the origin of these bacteria: continental or marine from our FA profiles.

Compound-specific stable carbon isotopic compositions of most fatty acids (except 20:5) became enriched along the transect from the prodelta to the shelf, similar to the results of the bulk OC isotopic compositions (Fig. 5 and Table 1). Although diagenetic processes may have important impacts on distributions of different compounds and their isotopic compositions, the similar $\delta^{13} \mathrm{C}$ variations between the total organic carbon pool and fatty acids clearly indicate mixed inputs of OM from different sources. In general, if $\mathrm{OM}$ from a terrestrial source is dominated by $\mathrm{C} 3$ plants, their $\delta^{13} \mathrm{C}$ (including compound-specific) values are relatively more negative than those from marine sources (Fig. 7). On this figure, surface sediments from the Rhône delta system appear close to the riverine and C3 end-members, indicating that Rhodanian suspended organic matter is the predominant source of $\mathrm{OM}$ in the prodelta area. A similar trend has been observed in June 2005 by Lansard et al. (2009). Furthermore, it shows that riverine inputs are essentially composed of soil-derived OM with a minor contribution from freshwater phytoplankton and no input from $\mathrm{C} 4$ vascular plants. This assumption is corroborated by recent estimates of the contribution of soilderived OM off the Rhône River mouth (Kim et al., 2010). On the basis of the Branched and Isoprenoid Tetraether (BIT) index, soil organic carbon accounts for $88 \%$ of the total organic carbon at the vicinity of the Rhône mouth (station A) and its contribution decreases seaward down to $11 \%$ at station $\mathrm{F}$.

Non-specific fatty acids (e.g. 14:0 and 16:0) are contributed by all organic matter sources and have distinct $\delta^{13} \mathrm{C}$ signatures from source to source (Canuel et al., 1997; Dai et al., 2005). The positive shift in $\delta^{13} \mathrm{C}$ of non-specific fatty acids along the transect reflects a variation in relative proportions of marine vs. terrestrial organic matter, and is consistent with those from our other molecular proxies. However, the mixing of OM from marine vs. terrestrial sources does not explain the trend of isotopic variations of source-specific fatty acids (e.g. $>\mathrm{C}_{20}$ LCFAs and 18:2 from terrestrial source vs. 16:1 from marine phytoplankton) along the transect. We

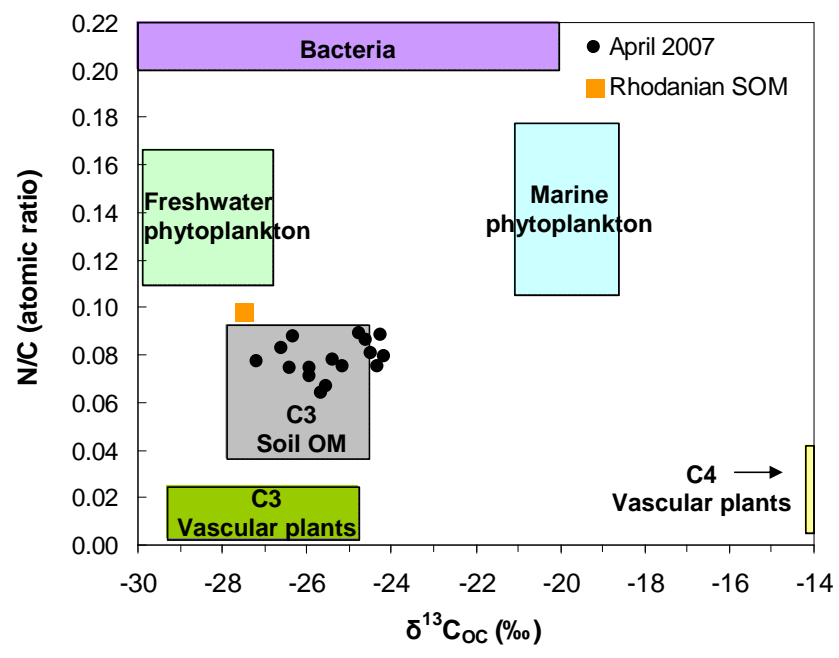

Fig. 7. Plot of atomic organic nitrogen:carbon ratios (N/C (atomic ratio)) versus the stable carbon isotopic compositions $\left(\delta^{13} \mathrm{C}_{\mathrm{OC}}\right)$ of surface sediments and suspended organic matter (SOM) from the Rhône River. Also plotted are the compositional ranges of potential end-member sources from the literature (Harmelin-Vivien et al., 2008; Melillo et al., 1989; Von Fischer and Tieszen, 1995; Vuorio et al., 2006; Goñi and Thomas, 2000; see citations in Meyers, 1994; and Maksymowska et al., 2000). In this diagram, N/C was plotted rather than its reciprocal because this ratio is statistically more robust and allows us to plot two parameters that are essentially carbon normalized (N/C and ${ }^{13} \mathrm{C} /{ }^{12} \mathrm{C}$ ratios, Goñi et al., 2005; Lansard et al., 2009).

will discuss the impact of OM degradation on the isotopic variations in the next section.

\subsection{Degradation state of the organic matter in the sur- face deposits}

THAA concentrations in surface sediments followed the general OC pattern of decreasing values along the SW transect, and resulted in a uniform distribution of THAA-C $\%$ and THAA-N\% with averaged values of $9 \%$ and $35 \%$, respectively. This suggests that there was no preferential degradation of the terrestrial proteinaceous material relative to bulk OC and TN. The THAA-C\% and THAA-N\% values in the Rhône prodelta fall within the range typical for coastal sediments (Lomstein et al., 2006; Unger et al., 2005a, b; Cowie and Hedges, 1992; Buscail et al., 1995). Amino acid composition has been shown to be relatively insensitive to OM sources due to the relative constancy of protein composition, but changes in their mole percentages are valuable indicators of diagenetic alteration (Cowie and Hedges, 1992, 1994; Dauwe et al., 1999). These changes in amino acid composition during the first steps of OM degradation may be more easily highlighted using the multivariate-based approach, i.e. "the degradation index" proposed by Dauwe and Middelburg (1998). The DI showed that material from the Rhône River was rapidly degraded seaward (Fig. 3) with values ranging 
from +0.1 in the innermost part of the prodelta to -0.4 on the continental shelf, suggesting that OM delivered by the river was reactive to chemical, physical and biological changes. The analysis of suspended particulate organic matter from the Rhône River indicates that riverine inputs were more enriched in THAA ( $238.0 \mathrm{mg} \mathrm{g}^{-1} \mathrm{OC}$, data not shown) than the surface deposits off the Rhône River mouth $\left(148.3 \mathrm{mg} \mathrm{g}^{-1}\right.$ OC, station A, data not shown). This suggests that riverine suspended material is subject to intensive processes of degradation in the water column or after deposition at the benthic boundary layer (Mayer et al., 2008). Comparison with data available in the literature suggests that $\mathrm{OM}$ from the Rhône prodelta was indeed moderately degraded (Unger et al., 2005a, b; Vandewiele et al., 2009; Lomstein et al., 2006) and this was confirmed in our samples by the fairly low amounts of non proteinic amino acids such as $\beta$-glutamic acid and $\beta$-alanine (less than $0.01 \mathrm{mg} \mathrm{g}^{-1} \mathrm{DW}, \mathrm{S}$. Bourgeois, unpublished results, 2010).

The general trend described by the DI values was further strengthened by another index of OM degradation, the PRI. Although chlorophyll pigments account for a small fraction of the OM pool, they are among the most labile organic compounds (Lee et al., 2000; Wakeham et al., 1997). The proportion of non-degraded chlorophyll- $a$ is thus a valuable indicator of OM freshness. The general covariance of terrestrial biomarkers (FAs, Chl- $b$ ) with the OM decomposition stage (PRI, DI) along the SW transect (Fig. 6a) suggests continuous degradation of the terrestrial OM during its transport from the river to the seafloor and once deposited. According to Durrieu de Madron et al. (2000), $84 \%$ of total POC inputs are recycled or degraded in the water column before reaching the sediments. Hence, both terrestrial and marine sources of OM are expected to be more degraded offshore, where the water is deeper. Since sediment discharge from the Rhône River plume decreases rapidly offshore, fewer riverborne particles settle on the seafloor in the adjacent shelf than at the river mouth (Durrieu de Madron et al., 2000). Moreover, river-borne sediments only remain transiently deposited in these highly disturbed environments since they are subjected to intensive reworking processes due to strong winds and currents (Marion et al., 2010) and two-thirds of the OM initially deposited in the Rhône prodelta may be resuspended (Beaudouin et al., 2005). The succession of resuspension and redeposition events increases the time of contact of the OM with oxygen and thus of aerobic degradation. Since labile components of the OM are preferentially degraded in the water column during resuspension (Raymond and Bauer, 2001), the OM deposited in the sediments becomes increasingly refractory.

From the prodelta to the shelf, $\delta^{13} \mathrm{C}$ values of sourcespecific fatty acids (e.g. LCFAs and 18:2 from terrestrial source and 16:1 from marine phytoplankton) increased, similar to those of non-specific compounds. The isotopic variations of these individual compounds are likely driven by degradation because they are from exclusive sources (no mixing). It has been observed (Chikaraishi and Naraoka, $2006)$ that in a plant-soil system, long-chain $\left(>\mathrm{C}_{24}\right) n$ alkanes, $n$-alkanoic acids and $n$-alkanols were gradually enriched in $\delta^{13} \mathrm{C}$ up to $+12.9 \%$ (average of $+4.3 \%$ ) from raw leaves to soils (with considerable degradation). Laboratory experiments (Sun et al., 2004) also confirmed that $\delta^{13} \mathrm{C}$ of phytoplankton-derived fatty acids become enriched (by a few \%o) when intensive degradation occurred. As discussed above, OM in this system was largely degraded with distance from the river mouth, along with isotopic enrichment of source-specific fatty acids. Thus, effects of diagenetic processes on molecular isotopic compositions could be important although the mechanism for isotopic alteration is not well documented.

In marine environments, heterotrophic bacteria play a key role in the degradation of suspended and settled OM during early diagenesis (Froelich et al., 1979; Berner, 1980). When normalized per gram of organic carbon, FAs derived from bacterial biomass are more abundant in the prodelta area (Fig. 4), which coincides with the higher rates of benthic remineralization measured in situ in this area during the same field work by Cathalot et al. (2010). A close relation between bacterial activity as estimated by bacterial biomarkers and the distribution of labile organic substrates (PUFAs and sterols) has been reported in sediments from the Eastern North Atlantic (Conte et al., 1995) highlighting that the sedimentary microbial community rapidly responds to the pulse of fresh phytodetritus. Bacteria synthesize branched iso- and anteiso-15:0 fatty acids with distinct isotopic compositions, depending on sources of organic materials they used (Boschker et al., 1999) and on environmental conditions (Teece et al., 1999). Relatively depleted $\delta^{13} \mathrm{C}$ of these bacteria-specific fatty acids in the nearshore stations indicates a predominant utilization of terrestrial $\mathrm{OM}$ by bacteria while for shelf stations, marine-derived $\mathrm{OM}$ is the main source for microbial synthesis of these compounds. A similar pattern was observed in the Altamaha estuarine system (Dai and Sun, 2007). The effective utilization of terrestrial OM by the bacterial compartment along with the positive relationship between the bacterial FA and chlorophyll- $a$ contents $(p<0.0001)$ suggests a clear coupling between Rhône River organic inputs and the intensity of microbial activity in the sediment.

\subsection{Nutritional quality of the sedimentary organic mat- ter and ecological implications}

In contrast to quantity and lability, bioavailability (EHAA/THAA) and nutritional quality (PUFA contents) of the sedimentary OM were not correlated with the distance from the Rhône River mouth (Fig. 6a). The index of OM digestibility (EHAA/THAA) remained constant ( $28 \%$ on average) in the area under the influence of the Rhône River with the exception of station N. The boundary between the prodelta and the adjacent shelf (i.e. station $\mathrm{N}$ ) 
is, moreover, characterized by the lowest PUFA contents. The projection of the 7 stations on the first plan of the PCA shows a boomerang-like distribution (Fig. 6b). OM from the inner part of the prodelta and from stations of the outer shelf appears to be more digestible and exhibits a higher nutritional quality. Between these two endpoints, the digestibility and nutritional quality of the sedimentary OM reach minimum values at the boundary between the prodelta area and the adjacent shelf (6 to $9 \mathrm{~km}$ from the river mouth). In this area, the land-derived inputs are low, as suggested by mean sediment accumulation estimates $\left(0.6 \mathrm{~cm} \mathrm{yr}^{-1}\right.$; Radakovitch et al., 1999), and are more degraded than in the inner part of the prodelta. The low nutritional quality of this matter is not yet fully compensated by the input of the marine-derived matter as is probably the case for the shelf stations.

PUFAs of the omega 3 series, in particular DHA and EPA, are essential for the growth and the reproduction of animals (see citation in Goedkoop et al., 2000). These two essential nutrients account for nearly $5 \%$ of the sediment FAs at the mouth of the river. The DHA:EPA is included in the 0.30.5 range reported by Budge et al. (2000) as being suitable for the growth of bivalve juveniles. Thus, OM delivered by the Rhône River appears as a food source of sufficiently high quality to support the development of benthic communities.

High EHAA-C\% indicative of the dominance of labile organic matter (Mayer et al., 2002) are found in the study area. Likewise, the fraction of bioavailable nitrogen (EHAA-N\%) in the superficial deposits from the prodelta was in the upper interval of the $2-10 \%$ range compiled by Mayer et al. (2008) for data from different coastal regions. Although this labile nitrogen accounts for a small fraction of the nitrogen delivered by the Rhône, it may be easily used by both microand macro-biota (Mayer et al., 2008). Moreover, a relationship between the growth rate of benthic invertebrates and the level of essential amino acids has been revealed by Marsh et al. (1989) on Capitella sp. I fed on a variety of food types. Accordingly, the relative contributions (\% mole) of the essential amino acids in the prodelta were higher than on the shelf (1.59 to $0.82 \mathrm{mg} \mathrm{g}^{-1} \mathrm{DW}$, respectively stations A and $\mathrm{F}$, data not shown).

Although terrestrial inputs are generally considered as more refractory than marine carbon, the Rhône River supplies large quantities of labile and nutritionally adequate particulate OM that may sustain the diversity, density and biomass of benthic communities. Several studies have shown the importance of terrestrial detritus for the benthic marine food web (Darnaude et al., 2004) and the dynamics of benthic macroinvertebrate communities (Salen-Picard et al., 2003; Hermand et al., 2008) on the coastal margin dominated by the Rhône River. Nevertheless, the Rhône prodelta is characterized by rapid and transient deposition of large amounts of fine particles. Such active deposition areas are characterized by adapted (Salen-Picard et al., 2003; Hermand et al., 2008) and stress tolerant taxa (Mojtahid et al., 2009; Goineau et al., 2011). A better understanding of the benthic communities structures in the area of the Rhône prodelta could be achieved by incorporating the molecular proxies of OM quality discussed in this paper in future studies.

\section{Conclusions}

Although the isotopic signatures of specific fatty acids in the sediments unambiguously demonstrate the input of marine $\mathrm{OM}$ in the shelf area, the coupling between the pelagic and benthic compartment was limited at this period of the year off the Rhône River. As a result, land-derived material is the main source of organic matter to the sediment in the Rhône prodelta as well as on the near adjacent shelf. Bulk isotopic measurements, fatty acid biomarkers and compoundspecific $\delta^{13} \mathrm{C}$ signatures of most fatty acids clearly indicate that the Rhône inputs consist of a mixture of OM from different sources with a strong contribution from soil and debris of C3 plants, and a smaller input from freshwater microalgae, mostly diatoms. Visual observations of the sediments confirm that detritus was composed of material at various degrees of decomposition, from decaying woody material to green leaves of duckweeds. This mixing of OM probably explains the intermediary value of Dauwe's degradation in$\operatorname{dex}(\mathrm{DI}=+0.1$ at the mouth site). Apart from being moderately degraded, these inputs are also labile as shown by the high proportion of bioavailable nitrogen and the occurrence of polyunsaturated fatty acids. The correlation between bacteria-specific fatty acids and chlorophyll- $a$, as well as the isotopic signature of the bacterial markers provides convincing evidence that the benthic microbial compartment is responding to these inputs of terrestrial material. Following the general trend for decreasing quantity of sedimentary OM (see Sect. 4.2), in situ, remineralization rates in sediments decrease from the mouth to the shelf (Cathalot et al., 2010).

There is a general assumption that terrigenous matter driven seaward by major rivers is refractory to decomposition (Ittekkot, 1988; Hedges et al., 1997). However, our multi-proxy study has revealed: (1) an offshore gradient of OM decay reflecting the rapid deposition of relatively labile terrigenous inputs in the prodelta, (2) the efficient degradation of the OM once deposited, and (3) the low mixing with fresh OM deriving from marine sources.

While biomarkers are useful to determine the origin of organic matter, they often only account for the fraction that is resistant to degradation (i.e. lignin products or branched and isoprenoid tetraethers). Our results highlight the need to combine specific descriptors of OM quality for a better assessment of the biochemical reactivity of land-derived OM in deltaic systems.

Acknowledgements. We would like to thank C. Rabouille, chief scientist of the RIOMAR-1 cruise and coordinator of the CHACCRA program for inviting us on this adventure. We thank the captain 
and crew of the RV Tethys II, as well as numerous CHACCRA colleagues, for their hard work at sea and in port. We are grateful to M. Desmalades and K. Escoubeyrou for their support at sea and in the laboratory, and to G. Jeanty who performed the elemental analyses. Hai Pan and Randolph Culp helped for isotope analyses. The technical assistance of N. Garro and K. Miegeville was greatly appreciated. We acknowledge A. Grémare for his initial input to the project proposal. We are grateful to S. Von Boletzky for the language revision of an earlier draft of the manuscript. We are indebted to J. Guarini-Coston for the correction of the style and the organisation of the paper of the final version. Finally, we would like to thank J. Volkman, T. Tesi and J.-J. Naudin whose comments helped improve this contribution.

This research was funded by the French National Research Agency, program "Vulnérabilités: Milieux et Climat" under the grant CHACCRA (contract number ANR-VULN-06-001-01), the French INSU-EC2CO program RiOMar.fr, and CNRS. Rhône River discharge data were provided by the server Inforhône of the Compagnie Nationale du Rhône (CNR). S. Bourgeois was supported by a grant from the French Ministry of Research.

Edited by: C. Rabouille

\section{References}

Aller, R. C.: Mobile deltaic and continental shelf muds as suboxic, fluidized bed reactors, Mar. Chem., 61, 143-155, 1998.

Alliot, E., Younes, W. A. N., Romano, J. C., Rebouillon, P., and Masse, H.: Biogeochemical impact of a dilution plume (Rhône River) on coastal sediments: comparison between a surface water survey (1996-2000) and sediment composition, Estuar. Coast. Shelf S., 57, 357-367, 2003.

Aloisi, J. C., Cambon, J. P., Carbonne, J., Cauwet, G., Millot, C., Monaco, A., and Pauc, H.: Origin and role of the bottom nepheloid layer in the transfer of particles into the marineenvironment - application to the Gulf of Lions, Oceanol. Acta, 5, 481-491, 1982.

Arnau, P., Liquete, C., and Canals, M.: River mouth plume events and their dispersal in the northwestern Mediterranean Sea, Oceanography, 17, 22-31, 2004.

Beaudouin, C., Suc, J. P., Cambon, G., Touzani, A., Giresse, P., Pont, D., Aloïsi, J. C., Marsset, T., Cochonat, P., and Duzer, D.: Present-day rhythmic deposition in the Grand Rhône prodelta (NW Mediterranean) according to high-resolution pollen analyses, J. Coastal Res., 21, 292-306, 2005.

Berner, R. A.: Early diagenesis: A theoretical approach, Princeton Univ Pr, 1980.

Boschker, H. T. S., de Brouwer, J. F. C., and Cappenberg, T. E.: The contribution of macrophyte-derived organic matter to microbial biomass in salt-marsh sediments: Stable carbon isotope analysis of microbial biomarkers, Limnol. Oceanogr., 44, 309-319, 1999.

Budge, S. M., Parrish, C. C., Thompson, R. J., and McKenzie, C. H.: Fatty acids in plankton in relation to bivalve dietary requirements, in: Seafood in health and nutrition, edited by: Shahidi, F., ScienceTech Publishing, St. John's, Canada, 495-520, 2000.

Budge, S. M., Parrish, C. C., and McKenzie, C. H.: Fatty acid composition of phytoplankton, settling particulate matter and sedi- ments at a sheltered bivalve aquaculture site, Mar. Chem., 76, 285-303, 2001.

Buscail, R., Pocklington, R., and Germain, C.: Seasonal variability of the organic matter in a sedimentary coastal environment: sources, degradation and accumulation (continental shelf of the Gulf of Lions-northwestern Mediterranean Sea), Cont. Shelf Res., 15, 843-869, 1995.

Canuel, E. A.: Relations between river flow, primary production and fatty acid composition of particulate organic matter in San Francisco and Chesapeake Bays: a multivariate approach, Org. Geochem., 32, 563-583, 2001.

Canuel, E. A., Freeman, K. H., and Wakeham, S. G.: Isotopic compositions of lipid biomarker compounds in estuarine plants and surface sediments, Limnol. Oceanogr., 42, 1570-1583, 1997.

Cathalot, C., Rabouille, C., Pastor, L., Deflandre, B., Viollier, E., Buscail, R., Grémare, A., Treignier, C., and Pruski, A.: Temporal variability of carbon recycling in coastal sediments influenced by rivers: assessing the impact of flood inputs in the Rhône River prodelta, Biogeosciences, 7, 1187-1205, doi:10.5194/bg7-1187-2010, 2010.

Cathalot, C., Rabouille, C., Tisnérat-Laborde, N., Kerhervé, P., Buscail, R., Bowles, K., Sun, M.-Y., Tronczynski, J., Lansard, B., Treignier, C., Pastor, L., and Tesi, T.: Continental shelf particles: a major aging reservoir for organic carbon in deltaic areas, Geochim. Cosmochim. Ac., submitted, 2011.

Cauwet, G., Gadel, F., Sierra, M. M. D., Donard, O., and Ewald, M.: Contribution of the Rhône River to organic carbon inputs to the northwestern Mediterranean Sea, Cont. Shelf Res., 10, 10251037, 1990.

Charmasson, S., Bouisset, P., Radakovitch, O., Pruchon, A. S., and Arnaud, M.: Long-core profiles of Cs-137, Cs-134, Co60 and $\mathrm{Pb}-210$ in sediment near the Rhône River (Northwestern Mediterranean Sea), Estuaries, 21, 367-378, 1998.

Chikaraishi, Y. and Naraoka, H.: Carbon and hydrogen isotope variation of plant biomarkers in a plant-soil system, Chem. Geol., 231, 190-202, 2006.

Christie, W. W.: Lipid analysis: isolation, separation, identification and structural analysis of lipids, 3rd ed., Oily Press, Bridgawater, England, 2003.

Conte, M. H., Eglinton, G., Madureira, L. A. S., Rabouille, C., Labeyrie, L., and Mudge, S.: Origin and fate of organic biomarker compounds in the water column and sediments of the eastern North Atlantic, Philos. T. R. Soc. B, 348, 169-178, 1995.

Copeman, L. A. and Parrish, C. C.: Marine lipids in a cold coastal ecosystem: Gilbert Bay, Labrador, Mar. Biol., 143, 1213-1227, 2003.

Cowie, G. L. and Hedges, J. I.: Sources and reactivities of aminoacids in a coastal marine environment, Limnol. Oceanogr., 37, 703-724, 1992.

Cowie, G. L. and Hedges, J. I.: Biochemical indicators of diagenetic alteration in natural organic matter mixtures, Nature, 369, 304307, 1994.

Dai, J. H. and Sun, M. Y.: Organic matter sources and their use by bacteria in the sediments of the Altamaha estuary during high and low discharge periods, Org. Geochem., 38, 1-15, 2007.

Dai, J. H., Sun, M. Y., Culp, R. A., and Noakes, J. E.: Changes in chemical and isotopic signatures of plant materials during degradation: Implication for assessing various organic inputs in estuarine systems, Geophys. Res. Lett., 32, L13608, 
doi:10.1029/2005GL023133, 2005.

Darnaude, A. M., Salen-Picard, C., and Harmelin-Vivien, M. L.: Depth variation in terrestrial particulate organic matter exploitation by marine coastal benthic communities off the Rhône River delta (NW Mediterranean), Mar. Ecol.-Prog. Ser., 275, 47-57, 2004.

Dauwe, B. and Middelburg, J. J.: Amino acids and hexosamines as indicators of organic matter degradation state in North Sea sediments, Limnol. Oceanogr., 43, 782-798, 1998.

Dauwe, B., Middelburg, J. J., Herman, P. M. J., and Heip, C. H. R.: Linking diagenetic alteration of amino acids and bulk organic matter reactivity, Limnol. Oceanogr., 44, 1809-1814, 1999.

Day, J. W., Hall, C. A. S., Kemp, W. M., and Yáñez-Arancibia, A.: Estuarine ecology, Wiley-interscience, 558 pp., 1989.

De Leeuw, J. W. and Largeau, C.: A review of macromolecular organic compounds that comprise living organisms and their role in kerogen, coal, and petroleum formation, in: Organic Geochemistry principles and applications, edited by: Engel, M. H. and Macko, S. A., Plenum Publishing, New York, 23-72, 1993.

Dittmar, T., Fitznar, H. P., and Kattner, G.: Origin and biogeochemical cycling of organic nitrogen in the eastern Arctic Ocean as evident from D- and L-amino acids, Geochim. Cosmochim. Ac., 65, 4103-4114, 2001.

Dunstan, G. A., Volkman, J. K., Barrett, S. M., Leroi, J. M., and Jeffrey, S. W.: Essential polyunsaturated fatty acids from 14 species of diatom (Bacillariophyceae), Phytochemistry, 35, 155161, 1994.

Durrieu de Madron, X., Abassi, A., Heussner, S., Monaco, A., Aloisi, J. C., Radakovitch, O., Giresse, P., Buscail, R., and Kerherve, P.: Particulate matter and organic carbon budgets for the Gulf of Lions (NW Mediterranean), Oceanol. Acta, 23, 717-730, 2000.

Froelich, P. N., Klinkhammer, G. P., Bender, M. L., Luedtke, N. A., Heath, G. R., Cullen, D., Dauphin, P., Hammond, D., Hartman, B., and Maynard, V.: Early oxidation of organic matter in pelagic sediments of the eastern equatorial Atlantic: suboxic diagenesis, Geochim. Cosmochim. Ac., 43, 1075-1090, 1979.

Gaye, B., Wiesner, M. G., and Lahajnar, N.: Nitrogen sources in the South China Sea, as discerned from stable nitrogen isotopic ratios in rivers, sinking particles, and sediments, Mar. Chem., 114, 72-85, 2009.

Gillan, F. T. and Hogg, R. W.: A method for the estimation of bacterial biomass and community structure in mangrove-associated sediments, J. Microbiol. Meth., 2, 275-293, 1984.

Goedkoop, W., Sonesten, L., Ahlgren, G., and Boberg, M.: Fatty acids in profundal benthic invertebrates and their major food resources in Lake Erken, Sweden: seasonal variation and trophic indications, Can. J. Fish. Aquat. Sci., 57, 2267-2279, 2000.

Goineau, A., Fontanier, C., Jorissen, F. J., Lansard, B., Buscail, R., Mouret, A., Kerhervé, P., Zaragosi, S., Ernoult, E., Artéro, C., Anschutz, P., Metzger, E., and Rabouille, C.: Live (stained) benthic foraminifera from the Rhône prodelta (Gulf of Lion, NW Mediterranean): environmental controls on a river-dominated shelf, J. Sea Res., 65, 58-75, 2011.

Goñi, M. A. and Thomas, K. A.: Sources and transformations of organic matter in surface soils and sediments from a tidal estuary (north inlet, South Carolina, USA), Estuaries, 23, 548-564, 2000.

Goñi, M. A., Cathey, M. W., Kim, Y. H., and Voulgaris, G.: Fluxes and sources of suspended organic matter in an estuarine turbidity maximum region during low discharge conditions, Estuar. Coast. Shelf S., 63, 683-700, 2005.

Gordon, E. S. and Goñi, M. A.: Sources and distribution of terrigenous organic matter delivered by the Atchafalaya River to sediments in the northern Gulf of Mexico, Geochim. Cosmochim. Ac., 67, 2359-2375, 2003.

Grémare, A., Medernach, L., DeBovee, F., Amouroux, J. M., Charles, F., Dinet, A., Vetion, G., Albert, P., and Colomines, J. C.: Relationship between sedimentary organic matter and benthic fauna within the Gulf of Lion: synthesis on the identification of new biochemical descriptors of sedimentary organic nutritional value, Oceanol. Acta, 26, 391-406, 2003.

Hammer, Ø., Harper, D. A. T., and Ryan, P. D.: PAST: paleontological statistics software package for education and data analysis, Palaeontol. Electron., 4, 1-9, 2001.

Harmelin-Vivien, M., Loizeau, V., Mellon, C., Beker, B., Arlhac, D., Bodiguel, X., Ferraton, F., Hermand, R., Philippon, X., and Salen-Picard, C.: Comparison of $\mathrm{C}$ and $\mathrm{N}$ stable isotope ratios between surface particulate organic matter and microphytoplankton in the Gulf of Lions (NW Mediterranean), Cont. Shelf Res., 28, 1911-1919, 2008.

Harmelin-Vivien, M., Dierking, J., Banaru, D., Fontaine, M. F., and Arlhac, D.: Seasonal variation in stable $\mathrm{C}$ and $\mathrm{N}$ isotope ratios of the Rhône River inputs to the Mediterranean Sea (2004-2005), Biogeochemistry, 100, 139-150, 2010.

Hayashi, M., Toda, K., Ishiko, H., Komatsu, R., and Kitaoka, S.: Effects of shifting $\mathrm{pH}$ in the stationary-phase of growth on the chemical-composition of Euglena gracilis, Biosci. Biotech. and Bioch., 58, 1964-1967, 1994.

Hedges, J. I. and Keil, R. G.: Sedimentary organic matter preservation: an assessment and speculative synthesis, Mar. Chem., 49, 81-115, 1995.

Hedges, J. I., Keil, R. G., and Benner, R.: What happens to terrestrial organic matter in the ocean?, Org. Geochem., 27, 195-212, 1997.

Hedges, J. I., Mayorga, E., Tsamakis, E., McClain, M. E., Aufdenkampe, A., Quay, P., Richey, J. E., Benner, R., Opsahl, S., Black, B., Pimentel, T., Quintanilla, J., and Maurice, L.: Organic matter in Bolivian tributaries of the Amazon River: A comparison to the lower mainstream, Limnol. Oceanogr., 45, 1449-1466, 2000.

Hermand, R., Salen-Picard, C., Alliot, E., and Degiovanni, C.: Macrofaunal density, biomass and composition of estuarine sediments and their relationship to the river plume of the Rhône River (NW Mediterranean), Estuar. Coast. Shelf S., 79, 367-376, 2008.

Ingalls, A. E., Lee, C., Wakeham, S. G., and Hedges, J. I.: The role of biominerals in the sinking flux and preservation of amino acids in the Southern Ocean along $170^{\circ} \mathrm{W}$, Deep-Sea Res. pt. II, 50, 713-738, 2003.

Ingalls, A. E., Aller, R. C., Lee, C., and Wakeham, S. G.: Organic matter diagenesis in shallow water carbonate sediments, Geochim. Cosmochim. Ac., 68, 4363-4379, 2004.

Ittekkot, V.: Global trends in the nature of organic matter in river suspensions, Nature, 332, 436-438, 1988.

Jeffrey, S. W.: A report of green algal pigments in Central North Pacific Ocean, Mar. Biol., 37, 33-37, 1976.

Kim, J. H., Schouten, S., Buscail, R., Ludwig, W., Bonnin, J., Damste, J. S. S., and Bourrin, F.: Origin and distribution of ter- 
restrial organic matter in the NW Mediterranean (Gulf of Lions): Exploring the newly developed BIT index, Geochem. Geophy. Geosy., 7, Q11017, doi:10.1029/2006GC001306, 2006.

Kim, J., Zarzycka, B., Buscail, R., Peterse, F., Bonnin, J., Ludwig, W., Schouten, S., and Damsté, J. S. S.: Contribution of riverborne soil organic carbon to the Gulf of Lions (NW Mediterranean), Limnol. Oceanogr., 55, 507-518, 2010.

Lansard, B., Rabouille, C., Denis, L., and Grenz, C.: In situ oxygen uptake rates by coastal sediments under the influence of the Rhône River (NW Mediterranean Sea), Cont. Shelf Res., 28, 1501-1510, 2008.

Lansard, B., Rabouille, C., Denis, L., and Grenz, C.: Benthic remineralization at the land-ocean interface: A case study of the Rhône River (NW Mediterranean Sea), Estuar. Coast. Shelf S., 81, 544-554, 2009.

Lee, C., Wakeham, S. G., and Hedges, J. I.: Composition and flux of particulate amino acids and chloropigments in equatorial Pacific seawater and sediments, Deep-Sea Res. Pt. I, 47, 1535-1568, 2000.

Lefevre, D., Minas, H. J., Minas, M., Robinson, C., Williams, P. J. L., and Woodward, E. M. S.: Review of gross community production, primary production, net community production and dark community respiration in the Gulf of Lions, Deep-Sea Res. pt. II, 44, 801-832, 1997.

Lindroth, P. and Mopper, K.: High performance liquid chromatographic determination of subpicomole amounts of amino acids by precolumn fluorescence derivatization with orthophthaldialdehyde, Anal. Chem., 51, 1667-1674, 1979.

Lomstein, B. A., Jørgensen, B. B., Schubert, C. J., and Niggemann, J.: Amino acid biogeo- and stereochemistry in coastal Chilean sediments, Geochim. Cosmochim. Ac., 70, 2970-2989, 2006.

Maksymowska, D., Richard, P., Piekarek-Jankowska, H., and Riera, P.: Chemical and isotopic composition of the organic matter sources in the Gulf of Gdansk (Southern Baltic Sea), Estuar. Coast. Shelf S., 51, 585-598, 2000.

Mann, K. H.: Ecology of coastal waters: a systems approach, Univ of California Pr, 322 pp., 1982.

Marion, C., Dufois, F., Arnaud, M., and Vella, C.: In situ record of sedimentary processes near the Rhône River mouth during winter events (Gulf of Lions, Mediterranean Sea), Cont. Shelf Res., 30, 1095-1107, 2010.

Marsh, A. G., Grémare, A., and Tenore, K. R.: Effect of food type and ration on growth of juvenile Capitella sp. I (Annelida: Polychaeta): macro- and micronutrients, Mar. Biol., 102, 519-527, 1989.

Mayer, L. M., Schick, L. L., Sawyer, T., Plante, C. J., Jumars, P. A., and Self, R. L.: Bioavailable amino acids in sediments: a biomimetic, kinetics-based approach, Limnol. Oceanogr., 40, 511-520, 1995.

Mayer, L., Benninger, L., Bock, M., DeMaster, D., Roberts, Q., and Martens, C.: Mineral associations and nutritional quality of organic matter in shelf and upper slope sediments off Cape Hatteras, USA: a case of unusually high loadings, Deep-Sea Res. pt. II, 49, 4587-4597, 2002.

Mayer, L. M., Schick, L. L., and Allison, M. A.: Input of nutritionally rich organic matter from the Mississippi River to the Louisiana coastal zone, Estuaries Coasts, 31, 1052-1062, 2008.

McKee, B. A., Aller, R. C., Allison, M. A., Bianchi, T. S., and Kineke, G. C.: Transport and transformation of dissolved and particulate materials on continental margins influenced by major rivers: benthic boundary layer and seabed processes, Cont. Shelf Res., 24, 899-926, 2004.

Meckler, A. N., Schubert, C. J., Cowie, G. L., Peiffer, S., and Dittrich, M.: New organic matter degradation proxies: Valid in lake systems?, Limnol. Oceanogr., 49, 2023-2033, 2004.

Melillo, J. M., Aber, J. D., Linkins, A. E., Ricca, A., Fry, B., and Nadelhoffer, K. J.: Carbon and nitrogen dynamics along the decay continuum: Plant litter to soil organic matter, Plant Soil, 115, 189-198, 1989.

Meyers, P. A.: Preservation of elemental and isotopic source identification of sedimentary organic matter, Chem. Geol., 114, 289302, 1994.

Millot, C.: The Gulf of Lions Hydrodynamics, Cont. Shelf Res., 10, 885-894, 1990.

Mojtahid, M., Jorissen, F., Lansard, B., Fontanier, C., Bombled, B., and Rabouille, C.: Spatial distribution of live benthic foraminifera in the Rhône prodelta: Faunal response to a continental-marine organic matter gradient, Mar. Micropaleontol., 70, 177-200, 2009.

Nahon, S., Charles, F., Lantoine, F., Vétion, G., Escoubeyrou, K., Desmalades, M., and Pruski, A. M.: Ultraviolet radiation negatively affects growth and food quality of the pelagic diatom Skeletonema costatum, J. Exp. Mar. Biol. Ecol., 383, 164-170, 2010.

Naudin, J. J., Cauwet, G., Fajon, C., Oriol, L., Terzic, S., Devenon, J. L., and Broche, P.: Effect of mixing on microbial communities in the Rhône River plume, J. Marine Syst., 28, 203-227, 2001.

Neveux, J. and Lantoine, F.: Spectrofluorometric assay of chlorophylls and pheopigments using the least squares approximation technique, Deep-Sea Res. Pt. I, 40, 1747-1765, 1993.

Nichols, B. W. and Appleby, R. S.: The distribution and biosynthesis of arachidonic acid in algae, Phytochemistry, 8, 1907-1915, 1969.

Nichols, P. D., Jones, G. J., Deleeuw, J. W., and Johns, R. B.: The fatty acid and sterol composition of two marine dinoflagellates, Phytochemistry, 23, 1043-1047, 1984.

Niggemann, J. and Schubert, C. J.: Fatty acid biogeochemistry of sediments from the Chilean coastal upwelling region: sources and diagenetic changes, Org. Geochem., 37, 626-647, 2006.

Perry, G. J., Volkman, J. K., Johns, R. B., and Bavor Jr., H. J.: Fatty acids of bacterial origin in contemporary marine sediments, Geochim. Cosmochim. Ac., 43, 1715-1725, 1979.

Petkov, G. D., Furnadzieva, S. T., and Andreeva, R. D.: Fatty acid and sterol composition on Nannochloris sp., Arch. Hydrobiol., 72, 133-135, 1994.

Phillips, N. W.: Role of different microbes and substrates as potential suppliers of specific, essential nutrients to marine detritivores, B. Mar. Sci., 35, 283-298, 1984.

Philp, R. P.: Geochemical characteristics of oils derived predominantly from terrigenous source materials, Geol. Soc. Spec. Publ., 77, 71-91, 1994.

Pont, D.: Les débits solides du Rhône à proximité de son embouchure: données récentes (1994-1995), Revue de géographie de Lyon, 72, 13-33, 1997.

Pont, D., Simonnet, J. P., and Walter, A. V.: Medium-term changes in suspended sediment delivery to the ocean: Consequences of catchment heterogeneity and river management (Rhône River, France), Estuar. Coast. Shelf S., 54, 1-18, 2002. 
Pujo-Pay, M., Conan, P., Joux, F., Oriol, L., Naudin, J. J., and Cauwet, G.: Impact of phytoplankton and bacterial production on nutrient and DOM uptake in the Rhône river plume (NW Mediterranean), Mar. Ecol.-Prog. Ser., 315, 43-54, 2006.

Pusceddu, A., Grémare, A., Escoubeyrou, K., Amouroux, J. M., Fiordelmondo, C., and Danovaro, R.: Impact of natural (storm) and anthropogenic (trawling) sediment resuspension on particulate organic matter in coastal environments, Cont. Shelf Res., 25, 2506-2520, 2005.

Radakovitch, O., Charmasson, S., Arnaud, M., and Bouisset, P.: $\mathrm{Pb}-210$ and caesium accumulation in the Rhône delta sediments, Estuar. Coast. Shelf S., 48, 77-92, 1999.

Raimbault, P. and Durrieu de Madron, X.: Research activities in the Gulf of Lions (NW Mediterranean) within the 1997-2001 PNEC project, Oceanol. Acta, 26, 291-298, 2003.

Raymond, P. A. and Bauer, J. E.: Riverine export of aged terrestrial organic matter to the North Atlantic Ocean, Nature, 409, 497500, 2001.

Rosenberg, R., Grémare, A., Amouroux, J. M., and Nilsson, H. C.: Benthic habitats in the northwest Mediterranean characterised by sedimentary organics, benthic macrofauna and sediment profile images, Estuar. Coast. Shelf S., 57, 297-311, 2003.

Salen-Picard, C., Arlhac, D., and Alliot, E.: Responses of a Mediterranean soft bottom community to short-term (19931996) hydrological changes in the Rhône River, Mar. Environ. Res., 55, 409-427, 2003.

Sanchez-Garcia, L., de Andres, J. R., Martin-Rubi, J. A., and Louchouarn, P.: Diagenetic state and source characterization of marine sediments from the inner continental shelf of the Gulf of Cadiz (SW Spain), constrained by terrigenous biomarkers, Org. Geochem., 40, 184-194, 2009.

Sargent, J. R. and Falk-Petersen, S.: The lipid biochemistry of calanoid copepods, Hydrobiologia, 167, 101-114, 1988.

Sargent, J. R. and Henderson, R. J.: Lipids, in: The biological chemistry of marine copepods, edited by: Corner, E., and O'Hara, S., Oxford University Press, Oxford, 59-108, 1986.

Schubert, C. J. and Nielsen, B.: Effects of decarbonation treatments on delta13C values in marine sediments, Mar. Chem., 72, 55-59, 2000.

Sempéré, R., Charrière, B., Van Wambeke, F., and Cauwet, G.: Carbon inputs of the Rhône River to the Mediterranean Sea: Biogeochemical implications, Global Biogeochem. Cy., 14, 669-681, 2000.

Shi, W., Sun, M. Y., Molina, M., and Hodson, R. E.: Variability in the distribution of lipid biomarkers and their molecular isotopic composition in Altamaha estuarine sediments: implications for the relative contribution of organic matter from various sources, Org. Geochem., 32, 453-467, 2001.

Sun, M. Y., Zou, L., Dai, J. H., Ding, H. B., Culp, R. A., and Scranton, M. I.: Molecular carbon isotopic fractionation of algal lipids during decomposition in natural oxic and anoxic seawaters, Org. Geochem., 35, 895-908, 2004.
Teece, M. A., Fogel, M. L., Dollhopf, M. E., and Nealson, K. H.: Isotopic fractionation associated with biosynthesis of fatty acids by a marine bacterium under oxic and anoxic conditions, Org. Geochem., 30, 1571-1579, 1999.

Tesi, T., Miserocchi, S., Goñi, M. A., and Langone, L.: Source, transport and fate of terrestrial organic carbon on the western Mediterranean Sea, Gulf of Lions, France, Mar. Chem., 105, 101-117, 2007.

Unger, D., Gaye-Haake, B., Neumann, K., Gebhardt, A. C., and Ittekkot, V.: Biogeochemistry of suspended and sedimentary material in the $\mathrm{Ob}$ and Yenisei rivers and Kara Sea: amino acids and amino sugars, Cont. Shelf Res., 25, 437-460, 2005a.

Unger, D., Ittekkot, V., Schafer, P., and Tiemann, J.: Biogeochemistry of particulate organic matter from the Bay of Bengal as discernible from hydrolysable neutral carbohydrates and amino acids, Mar. Chem., 96, 155-184, 2005 b.

Vandewiele, S., Cowie, G., Soetaert, K., and Middelburg, J. J.: Amino acid biogeochemistry and organic matter degradation state across the Pakistan margin oxygen minimum zone, DeepSea Res. pt. II, 56, 376-392, 2009.

Volkman, J. K., Jeffrey, S. W., Nichols, P. D., Rogers, G. I., and Garland, C. D.: Fatty acid and lipid composition of 10 species of microalgae used in mariculture, J. Exp. Mar. Biol. Ecol., 128, 219-240, 1989.

Volkman, J. K., Barrett, S. M., Blackburn, S. I., Mansour, M. P., Sikes, E. L., and Gelin, F.: Microalgal biomarkers: A review of recent research developments, Org. Geochem., 29, 1163-1179, 1998.

Von Fischer, J. C. and Tieszen, L. L.: Carbon isotope characterization of vegetation and soil organic matter in subtropical forests in Luquillo, Puerto-Rico, Biotropica, 27, 138-148, 1995.

Vuorio, K., Meili, M., and Sarvala, J.: Taxon-specific variation in the stable isotopic signatures (delta13C and delta15N) of lake phytoplankton, Freshwater Biol., 51, 807-822, 2006.

Wakeham, S. G. and Canuel, E. A.: Degradation and preservation of organic matter in marine sediments, in: The Handbook of Environmental Chemistry, edited by: Volkman, J. K., 295-321, 2006.

Wakeham, S. G., Lee, C., Hedges, J. I., Hernes, P. J., and Peterson, M. L.: Molecular indicators of diagenetic status in marine organic matter, Geochim. Cosmochim. Ac., 61, 5363-5369, 1997.

Wannigama, G. P., Volkman, J. K., Gillan, F. T., Nichols, P. D., and Johns, R. B.: A comparison of lipid components of the fresh and dead leaves and pneumatophores of the mangrove Avicennia marina, Phytochemistry, 20, 659-666, 1981.

Waterson, E. J.: Sources of sedimentary organic matter in the Mississippi River and adjacent Gulf of Mexico, The College of William and Mary, 2005. 